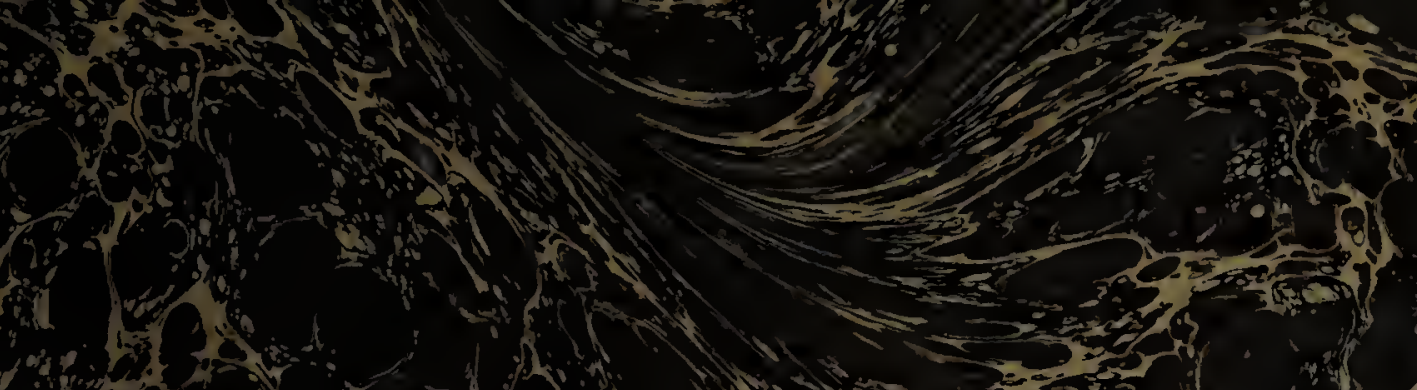

(5) $\left(\frac{1}{2}+2\right)$

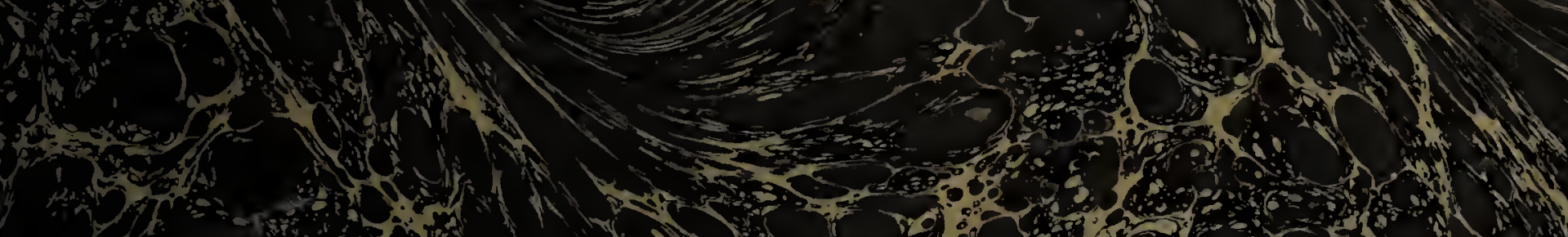
6.t.

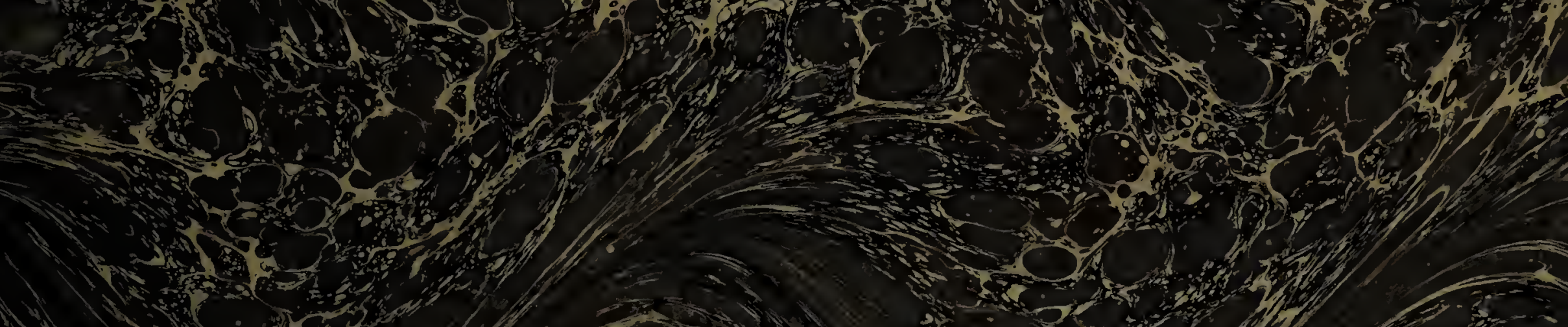

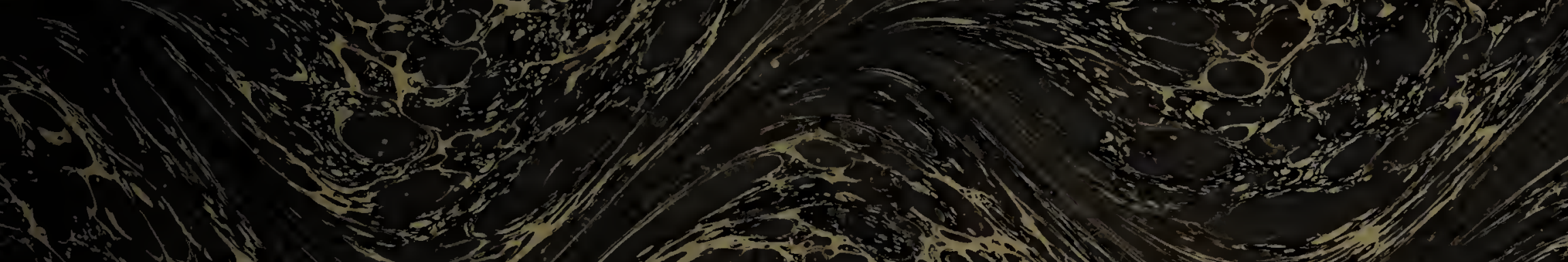

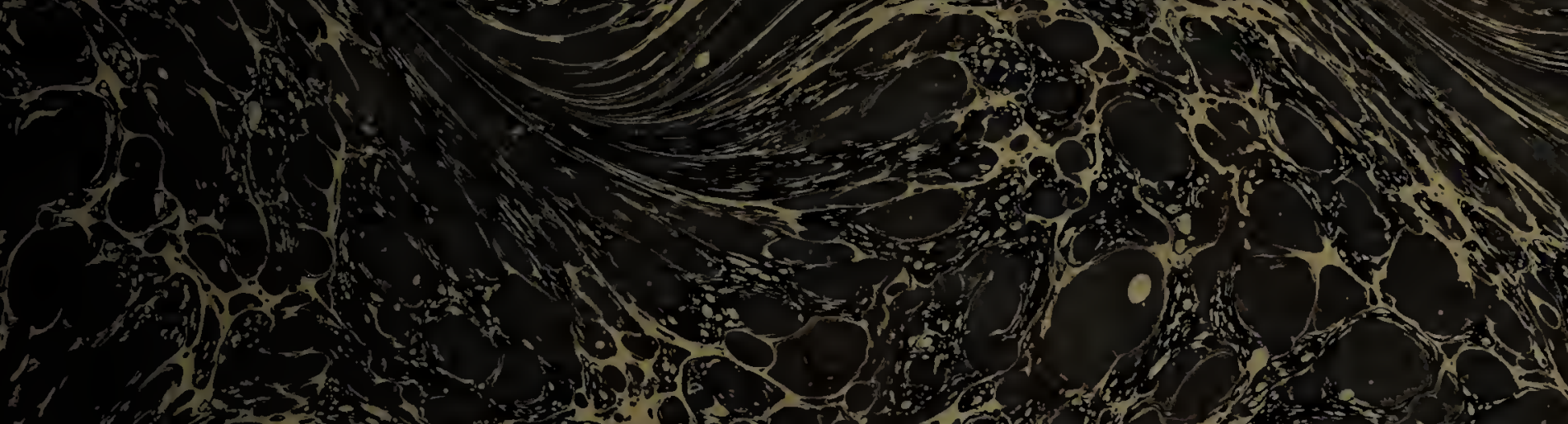
-

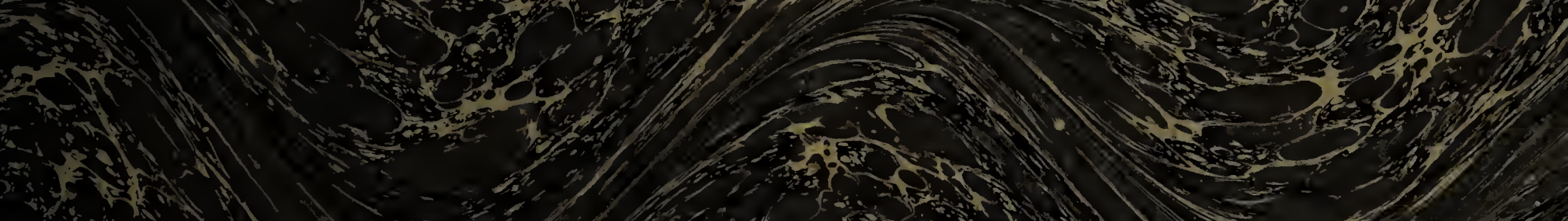

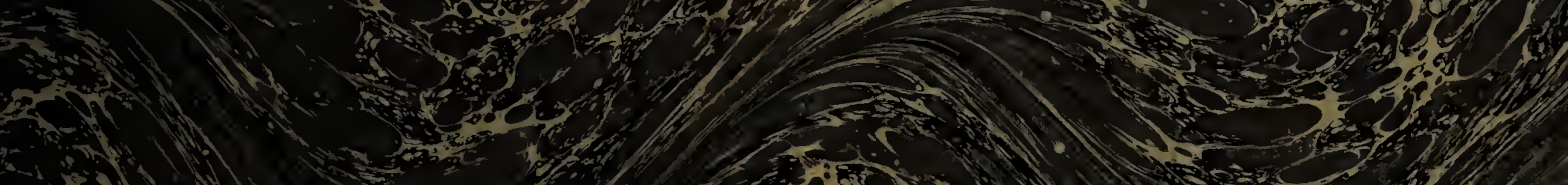

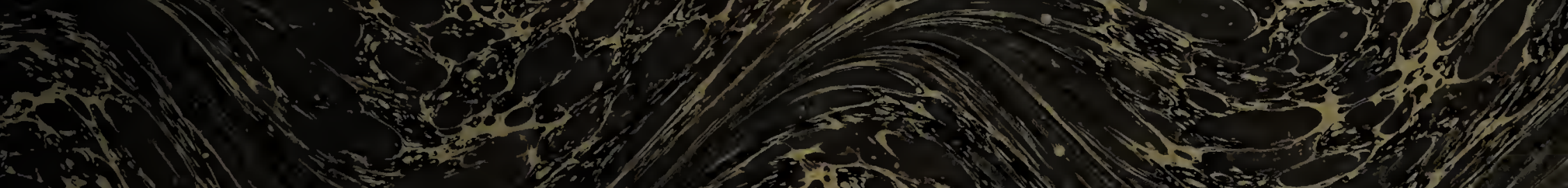

sents 3)

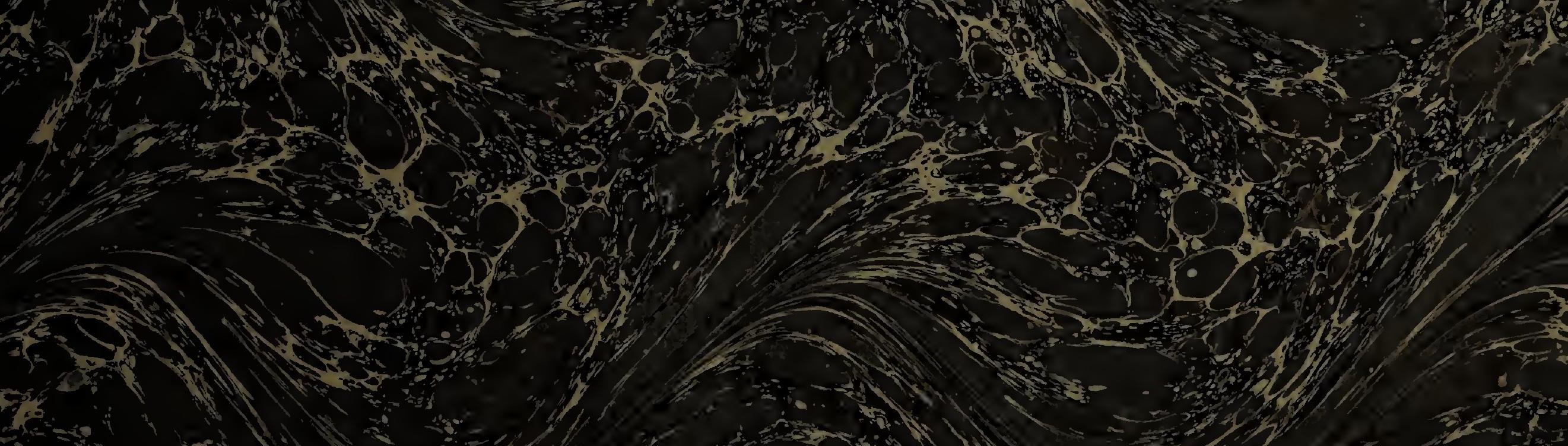





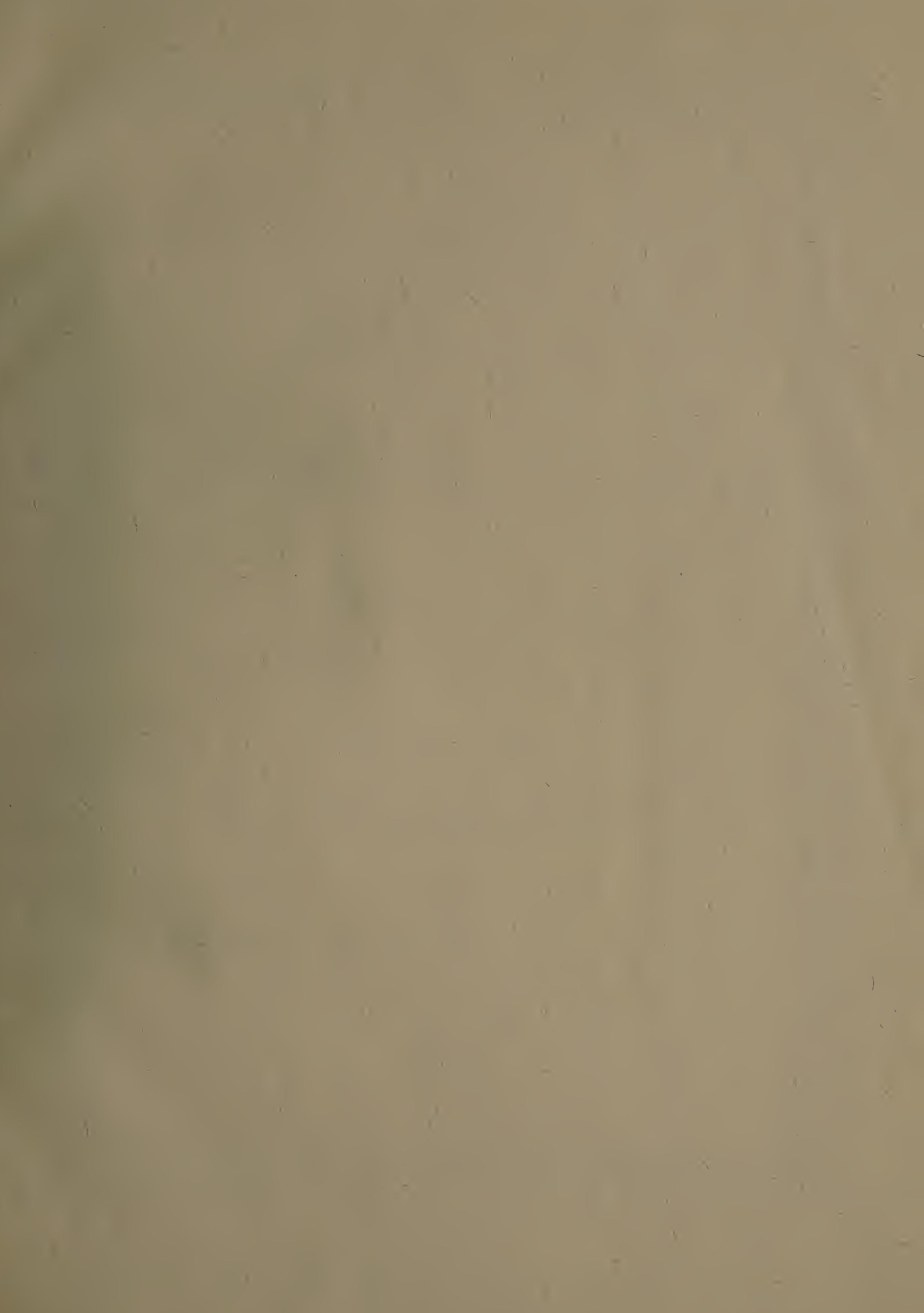





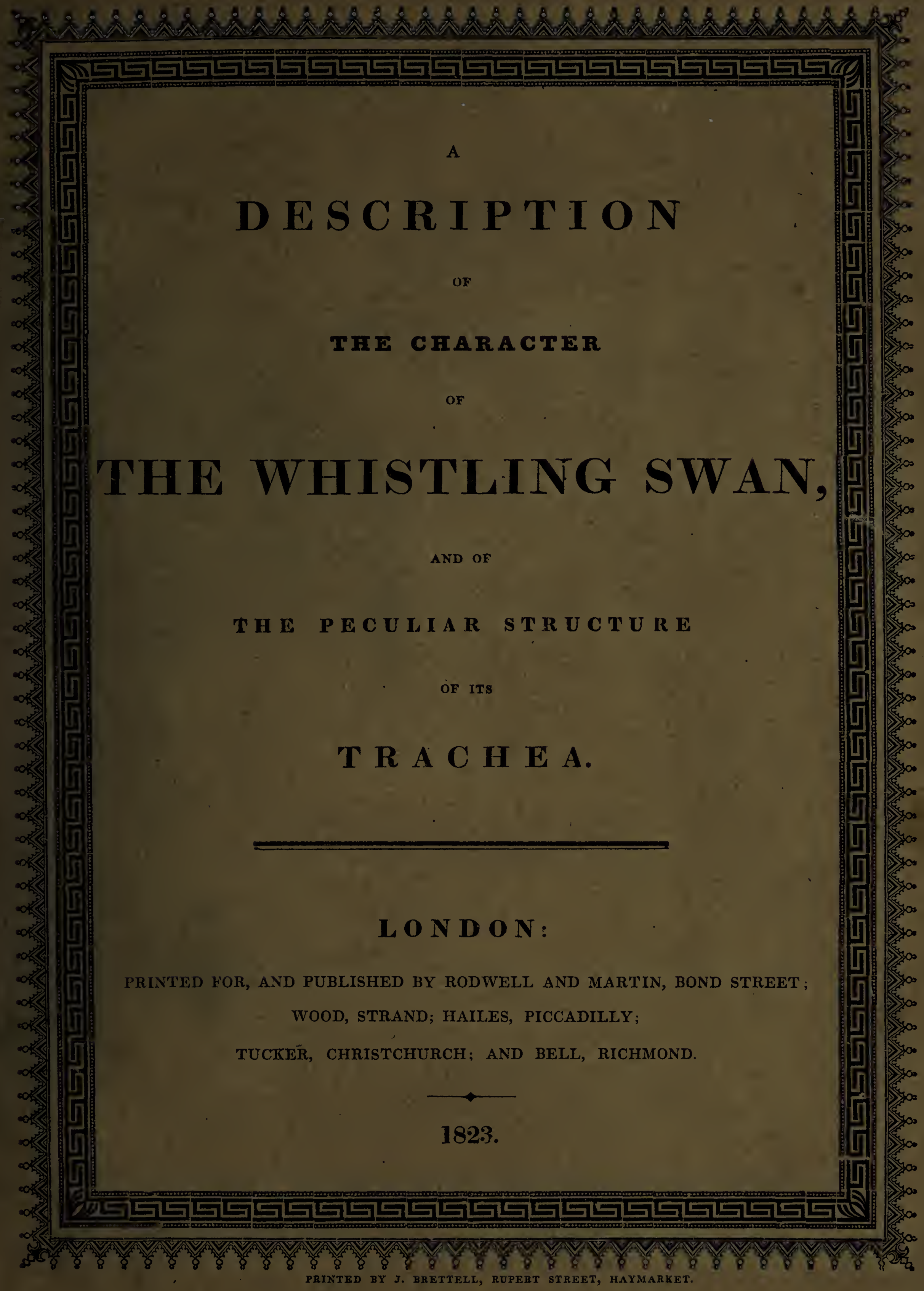



COOKE, T. 


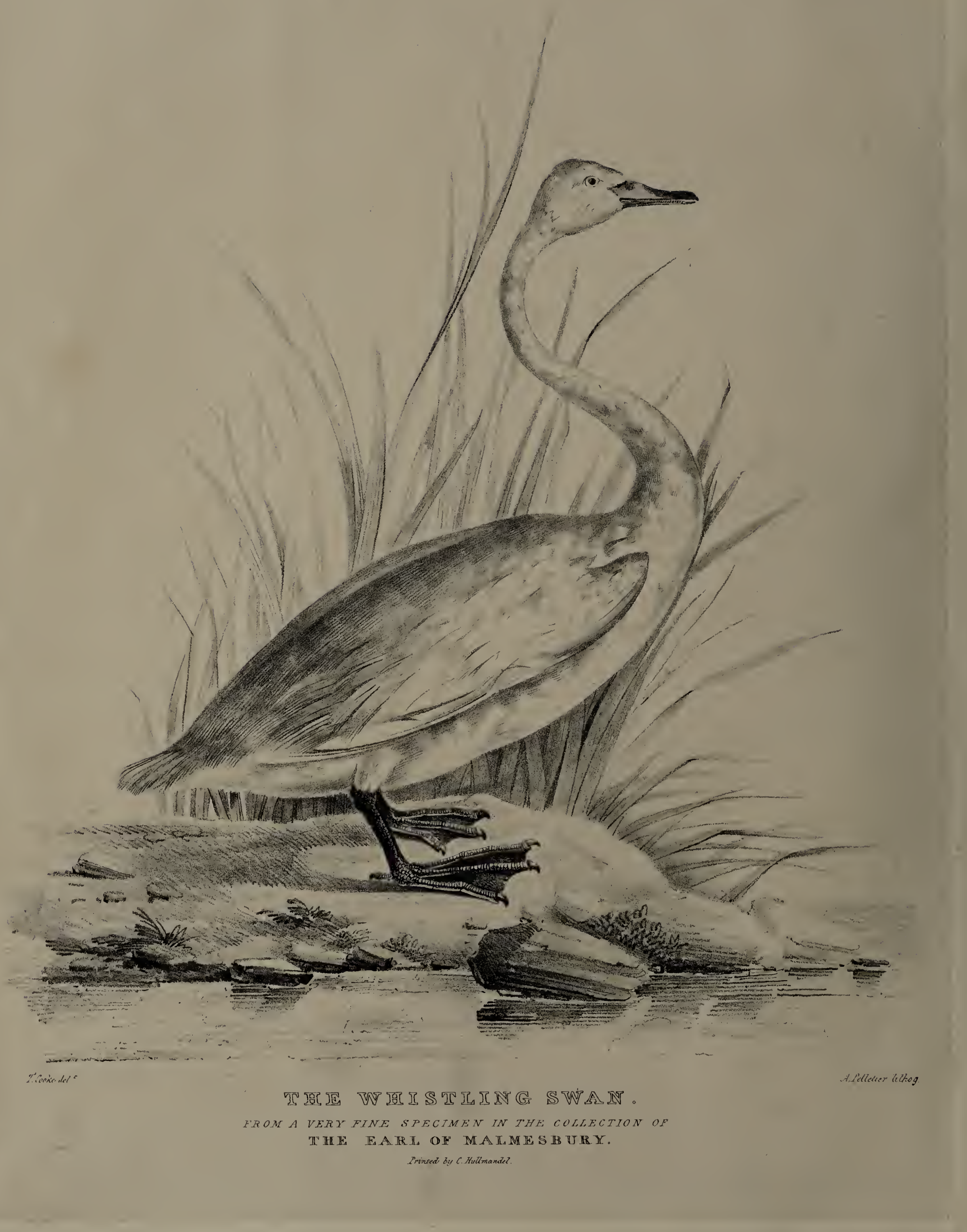




\section{A \\ LETTER}

To

M A R K M I L B A N K, E S Q. M.P.

or

THORP HALL, AND BARNINGHAM, IN THE COUNTY OF YORK,

WITH TWO PLATES,

DESCRIPTIVE OF THE CHARACTER

of

\section{THE WHISTLING SWAN,}

AND OF

THE PECUIIAR STRUCTURE

of ITs

T RA C H EA.

AMICO MUNUSCULUM LEVIDENSE.

Cic. Ep. Fam. L. ix. 12.

\section{LO N D O N :}

PRINTED FOR, AND PUBLISHED BY RODWELL AND MARTIN, BOND STREET; WOOD, STRAND; HAILES, PICCADILLY;

TUCKER, CHRISTCHURCH; AND BELL, RICHMOND.

1823. 


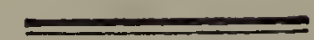

Anas, Cycnus ferus.-Lin. Syst.

Le Cygne Sauvage.-Buffon, Temminck, \&.c.

Elk, Hooper: Wild, or Whistuing Swan.-Willoughby, Edzoards, \&c.

Anas, rostro semicylindrico, atro, cerâ flavâ, corpore albo. Habitat in Europâ, Asiâ, et Americâ. Asperitate hyemis compulsus interdum in Angliâ videtur.

Tracnea mirabili prorsus modo sternum ingreditur, inibique reflectitur, et post digressum ad divaricationem in angustum spatium coarctatur, non annulis, sed latâ et osseâ cartilagine, deinde in duos ramos divisa ad pulmones tendit.-Latham, Syn.

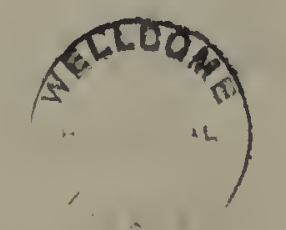

PRINTED UY J. BRETTELL, RUPERT GTREET, HAYMARKET. 
HERON COUPT, NEAR RINGWOOD, HANTS, June 7 th, 1823.

\section{DEAR MILBANK,}

ThE severity of the winter has supplied me with many subjects worthy of the attention of the Ornithologist, and I have employed some leisure moments in collecting information respecting them, with a view to requite the kindness, with which you have sent me an account of your observations in your own neighbourhood.

As soon as I had dispatched my communication of the 26th of January, to report the arrival of the Scaup Duck, the Great Northern Diver, the Meigus Merganser, and the White Nun, or Smew, my ears were struck by the sound of a regular beating of wings, and of a loud shrill grating cry.Before I could look up towards the window, a broad shadow obscured the room. A flock of birds passed round the house from the North-East to the South-West, in close flight, the bills of those in the rear seeming to rest upon the tails of those who led the way. I counted about thirty. Half of them were entirely white, the rest partially grey, and all of a size disproportionate to the general features of our landscape.

These unlooked for visitors proved to be a detachment from a body of more than a hundred Whistling Swans, who had advanced beyond the usual bounds of their Southerly migration. I afterwards fell in with them frequently in my walks in the vicinity of Ramsdown. Sometimes I found them riding, like a naval squadron, upon the wide waters which overspread the great Heron Meadow during the inundations of the Stour; and at other times stalking on the marshy swamps, which the Avon traverses in its course to Christchurch Twineham, where the two rivers meet, before they discharge themselves into the sea. With the assistance of a telescope, I could watch their movements from a considerable distance, and observe them when engaged at their toilette, " bathing their snowy bosoms;" when eager in the pursuit of food; and when taking their turn of sleep, with their heads under their wings, whilst others of the party, like the watch boats of a fleet, were sailing round to protect them.

But these emigrants did not long remain thus unmolested. They had taken possession of their quarters with too much noise and too conspicuous a display of their colours to escape notoriety. Preparations for warfare were visible. The days of the Pygmies and their aërial invaders seemed to be renewed. A white bird, rudely figured with chalk upon the black hat of a Forester, looked like the first signal of defiance.-In good truth, a campaign was opened, with as little mercy and forbearance as you have seen to accompany an attack upon an intruding fox in the South Hams of Devon. The watermen in the harbour cleansed their artillery for action-the long guns were taken from the dusty rack over the farmer's fire-place-the plough-boy left his play, and sought a barrel of a calibre suited to his marbles, which he actually fired at " the great creatures," instead of ball. The tranquillity, if not the existence of other animals, was endangered, but,

To tell you the truth, no mischief was done,

Save spoiling the Proverb, " as sure as a gun,"

If I except the consequence of $a$ piece of awkwardness reported of $\longrightarrow$, who shot at one of " those Hoopers," and unfortunately killed a grazier's cow. 
I was long in doubt, whether these hostile measures would furnish me with a captive, either alive, or dead, which I might preserve for you. The difficulty of obtaining a specimen was greater than you may imagine. The strangers bring with them a wariness in their aciions greatly conducive to their safety. They avoid trees and bushes, as well as men,-every thing indeed, which is different from the uninterrupted tracts of land, or water, in Kamtschatka, Tartary, and Lapland. They fly, for the most part, in elevated regions far out of the scope of shot; and although their wings do not, because of their weight, size, and regular vibration, seem to move fast, every stroke of their pinions carries them through an almost incredible space, and with great rapidity. Hence the marksman, who does not make other calculations than those applicable to ordinary wild fowl, who fires at this bird, instead of some distance before it, always misses his aim. It swims with uncommon celerity, sometimes elevating its wings, and employing them as sails, in addition to its natural oars.

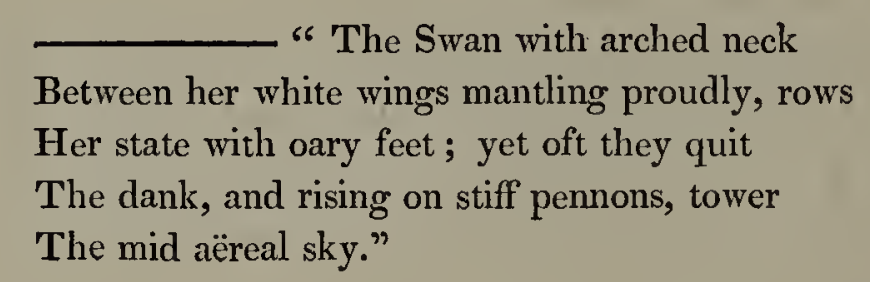

With its long neck it commands the banks of the rivers, from which the fowler successfully in other cases comes down upon his web-footed prey, who are not aware of his approach, until the engine of destruction has been levelled at their heads.

On the 5th of February, a plan of operations was agreed upon, under the superintendence of a skilful and indefatigable sportsman. It had been ascertained, that about seventeen of the Swans had settled in the large meadow, which I have already named, containing about a hundred acres, at that time entirely under water. To approach them in that situation was impossible. It was desirable therefore to drive them to a spot, whence a gun might reach them. The Stour enters at the Western extremity of the mead, dividing it at that point from a series of other equally open meadows. To the North and South lie enclosed pastures. The Eastern boundary is formed by a continued line of plantation. Behind this runs the high road, on which the sportsman and a keeper took their position, having the power of moving on it, either Northward, or Southward, according to the course that might be taken by the birds. In the Northern enclosures a man was posted, who was to shew himself when the birds should take wing, to prevent their flying in that direction. There was not much probability of their going towards the South, because they had invariably commenced their flight against the wind, which blew, on that morning, from the North-North-East. An active and intelligent man was sent on horseback to the Western side of the meadow, and he was directed to ride towards the Swans, at a slow pace, and to tack and turn occasionally for a hundred yards, to the right and left, for the purpose of forcing them towards the ambuscade. Less precaution however might have been taken on that occasion, for they allowed him to approach very near to them : and, in spite of his shouting, and the splashing of his horse, they would only waddle, or swim leisurely where there was sufficient depth of water, or skim the surface for a short distance, and pitch again. One bird, distinguished by his magnitude, and the whiteness of his plumage, seemed to be actively engaged in impelling forward the more sluggish with his bill and wings. At length they became sufficiently alarmed to rise from the water, and flew directly towards the before-mentioned plantation; but having approached within a short distance of it, they turned their course, and skirted its outline, at the height of about twenty-five yards. Aware of this manœuvre, the concealed sportsman hastened to a spot, where he found himself thirty yards distant from the flock, and then 
he shot at the most conspicuous bird. It did not immediately shew any symptoms of having been struck. They all proceeded, apparently heedless of the noise of the gun, and of the clattering of the bullets. But, after they had gone on together about a hundred and fifty yards, the object of his aim paused suddenly in the air, with a convulsive extension of its wings, drooped its head, and fell a lifeless mass into the water beneath. The prize was borne in triumph to my apartment for inspection. The Roc of the Arabian tale could not have been a more imposing spectacle. When held by the throat, its feet touching the floor, it over-topped the head of a man of moderate height, and the load seemed to be too much for a single hand.

It was a fine specimen for preservation. The single bullet, with which there were thirteen to the load, had passed through the heart, and left scarcely any external mark of injury.

It measures in extreme length five feet three inches, and in extreme breadth, the wings expanded, seven feet ten inches, - the size I have reduced in the drawing, which accomparies my letter, on a scale of two inches to a foot. It weighed, when first brought in, exactly twenty-four pounds.

The bill is four inches long, with an elastic process on the upper mandible, and covered, as far as two-thirds of the base, with a yellow membrane, bare of feathers, rising from the eyes. The nostrils are oval, and slightly fringed with yellow, but the remaining part of the bill to the end of its nail is black, with an angular seam upon the arch of the upper mandible. The lower mandible is externally flat. Both are serrated, for the purpose of cutting weeds and roots, and perhaps of straining off the foul water from them. The tongue is broad and flat, serrated, and of a fleshy colour. The pupil of the eye is black. The irides are of a bright yellow. The eyelids are yellowish. The crown of the head is not more arched than that of a goose. Its wings are armed with a sharp horny spur, confined to this species, about three quarters of an inch long, hardly visible, until the coverts of the alula spuria are removed. The tail consists of twenty feathers.

Its plumage is beautifully white, studded with a few faint rust-coloured, or light orange spots around the head and neck, which spots are by some supposed adequately to account for the epithet "Purpureus" ascribed to it by Horace. But the term may be better suited to the dazzling effect produced by a snowy white body, " dark with excess of light." Still more appropriate would it be to the deep blue, or grey feathers, which adorn the head and wings of this class, until after they have left the nest for a year or two. But the change is very gradual; for this species is both a longer time in the shell, and more tardy in coming to maturity, in every respect, than any other of the feathered tribe.

The legs of the stuffed specimen are large, and bear evident marks of age. Its feet have three toes before, united by a broad web. The hinder toe is very small in proportion to the other parts of its figure. It has a fine down under the feathers, which might be employed for many useful and elegant purposes, (although powder puffs are out of fashion;) and the skin of its legs would make an excellent imitation of shagreen for the outside of jewel-caskets and etuis.

You will compare this portrait with the mute Swans upon your lake, and remark some external characteristics, which distinguish the two species, which Buffon persisted in tracing to the same origin. The want of the black callous tubercles on the forehead, and of the membrane of the same colour beneath them; the black bill, instead of a red one with black edges, and tip ; the spur on the alula spuria; its more slender, and more graceful form, its more erect attitudecaused by the less forward situation of its legs, are all decided marks of difference, some of which may possibly be subject to alteration under the influence of a change of climate, and of food, added to domestication.

But the anatomy of the interior places an insurmountable line of demarcation between the two species, and therefore I protest against the term "Wild Swan," when applied to the Hooper, as of the same class with that oî our tame or mute. species, (for in Russia the Whistling Swan is that which is most commonly found tame,) under a different mode of existence. 
I cannot, with Pennant, contend for an unequal number of ribs. He says, that the mute Swar has only eleven on each side, and that the Whistling Swan has twelve. But these bones really increase in number, according to the age of the bird. Upon their skeletons at Mr. Brookes', at Mr. Yarrell's, and at the College of Surgeons, I have counted from seven to ten, but never so many as twelve.

The Trachea of the mute Swan enters the chest immediately from the neck, as in the case of the generality of birds. But the Trachea of the specimen before me, descends from the glottis with the cesophagus, and separates itself from it about four inches from the last vertebra of the neck, and is received, through a hole in a tough membrane, into a cavity about three inches deep in the keel of the breast-bone. It traverses the bottom of this cavity to the end, where it is redoubled like a trumpet, and carried outwards through another hole in the same membrane. The arch of the furcula, or merry-thought, embraces both these plications, being itself formed in a very singular shape. At the orifice of the cavity the pipe is again turned up, and bent back into the thorax. Here the single circular tube ends in a compressed bony substance, shaped like the mouth-piece of a bassoon, which we will call the lower larynx, from which proceed two bronchi, which are somewhat enlarged about half way between the point of divarication, and their union with the two lobes of the lungs. The circular folds of the pipe are closely enveloped by the outward skin, and are secured from any change of shape injurious to respiration by strong and tightly-drawn ligamerits, attached to the clavicle, on one of which it rests on its entry into the cavity, and on two others on its return; whilst the bone effectually defends the plications within the receptacle from any external pressure, or mutual embarrassment. The nature of the Trachea itself contributes to this preservation of its tubular character. For it consists of a considerable number of strong bony rings, lined through the inside with an elastic membrane, and covered on the outside with several thin skins; and it accommodates itself casily to all the varied movements of the neck, by means of small fibres which pervade its whole length. The phrenomenon of the flexure in the keel was first noticed by. Ulysses Aldrovandus, Professor of Philosophy and Medicine in Bologna, at the commencement of the sixteenth century, and not by any of the Bartholini, the eldest of whom lived in 1616, who himself, I think, refers to Aldrovandus' àthority for some opinions on this subject. It has been treated of in the Philosophical Transactions for 1765, by Dr. Parsons; and in those of the Linnæan Society for 1797, by Dr. Latham, who has far exceeded his predecessors in nicety of remark, and in clearness in arranging and imparting information.

Montague, in the Supplement to his ingenious and instructive Dictionary, has contradicted his former statement; which, agreeing with Dr. Latham's opinion, asserted that this formation was common, in the same degree, and under the same circumstances, to the Whistling Swan of both sexes, (if I recollect rightly, Blumenbach says, that the male alone has any unusual curvature, and has given a detail of a still more irregular structure of the male in this particular. The Trachea of the other sex, says he, instead of returning to the mouth of the cavity, when it has reached the distance already defined, and beyond which, in the female, the excavation does not extend, is carried on through a lengthened sheath to the end of the kcel, and there enter's the breast-bone itsclf, in which the flexure is constrained to change its direction from a vertical, to a horizontal position, becoming orbicular, by being greatly extended laterally, and filling up the whole of the lower part of the breast-bone, quite down to the sternum. He adds, that the lower part of the cavity, which receives this Trachea, is very convex on the inside, (of the sternum,) and that the bone is so extremely thin, (but not " membranaceous,") that through it the sinuous course of the pipe is easily discerned; also, that the lower part of the keel of the breast-bone, where the Trachea turns, in order to take a horizontal direction, is much broader than it is in the female; whilst the Trachea itself is smaller in diameter, but considerably longer, (as it ought to be, to admit of this prolongation of its circuit,) and is attached 
to more capacious bronchi, whiclı proceed to their ramifications into the air vessels of the lungs from a larynx not so closely compressed.

This is a statement, which I have been anxious to establish, or refute, but without satisfactory success. In the male specimen before me, and in many other male specimens which have been examined this season by some eminent comparative anatomists, no such sexual difference has been observed. But after a long investigation at Mr. Brookes' unrivalled Museum, in which he assisted me with great zeal and kindness, I found a single sternum, presented to him by Dr. Leach, with the very appearance described in the above quotation from Montague. At some future time I will give you an outline of this occasional variety, and endeavour to account for a deviation, which, it is remarkable, Dr. Parsons seems to have met with, and to lave passed it without an observation, unless he has violated the rules of perspective, to give a representation of the interior contents of the cavity, in one of his figures.

The utility of any sort of curvature is not yet well understood. It probably conduces in some degree to sound, and modulation. It is also calculated to retain the inspired air, and thus to continue a supply of oxygen for a length of time, and therefore must be of great advantage to the animal, whilst it seeks its food by plunging its head and neck into the water, or whilst it flies through a rarified atmosphere.

It is to the species of Swan possessirng this peculiarity that we must apply what Poets, Historians, Naturalists, and Philosophers have said respecting its habitual note, and those angelic strains, with which it has been supposed to breathe out its life.

This fable is now perhaps utterly exploded. It is only strange that it should so long, and so completely have captivated the minds of men of deep learring, and good sense, as well as of poetical imagination. Yet no one can regret the past prevalence of this ill-founded idea, who has had his thoughts raised, or his fancy delighted by the dignified sentiments, and fine touches of feeling, to which it has given rise. I could recite a passage from the divine philosopher, full of a glimmering hope of immortality, founded on the vocal and prophetic qualities of these imaginary songsters. I will content myself, however, with referring you to his Phædo, page 85, of the first volume of Stephens' edition. A paragraph often quoted from Cicero's Treatise, de Oratore, must be familiar. to you.

But the praises bestowed upon the voice of these mythological minstrels of Apollo are ill supported by the evidence of our senses, according to which the boasted melody of the Swan is, at best, but a discordant union of the shout of a cuckoo with the screaming of a gull; or, like the music of those expressive lines in Lycidas:-

$$
\begin{aligned}
& \text { " they are sped, } \\
& \text { And when they list, their lean and flashy songs } \\
& \text { Grate on their scrannel pipes of wretched straw." }
\end{aligned}
$$

Pennant, indeed, says, that it utters its loud notes, when flying, or calling with a sound, like whooph, whooph, very strong, and slurill, but not disagreeable, when heard far above one's head, and modulated by the winds. This last is a qualification added by Anacreon:-

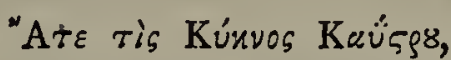

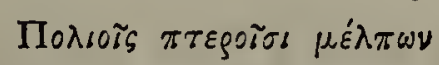

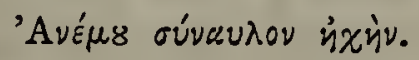

A passage, which possibly induced Gregorius Nazianzenus to represent the Swans as promising the music of their feathers breathed upon by the winds to those who would seek them in sequestered 
solitudes. Philostratus also thought that the Swan's most pleasant harmony was produced by the influence of the zephyrs upon its wings. I quote a passage from his illustration of the picture of

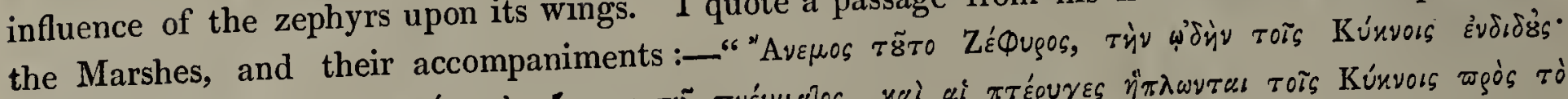

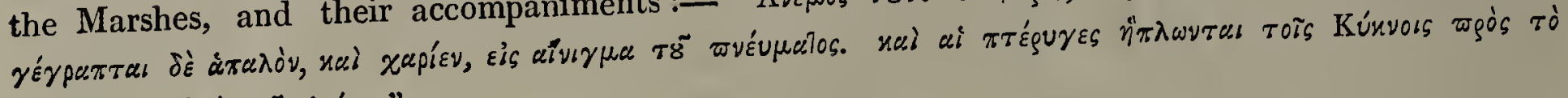

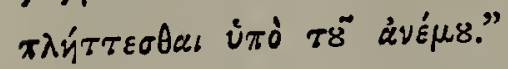

The natives of Iceland, according to Pennant, compare the notes of the Swan to those of a violin; and no wonder, for they hear them first at the termination of a long and dreary winter, when the return of this bird is the harbinger of spring. Every sound therefore must be grateful, which presages the speedy thaw, and a release from tedious confinement.

It is not my intention to enter into the grave argument, which has been held on the question, whether Swans were sweetly vocal, or not. But I would maintain, that if the antients differed amongst themselves concerning the fact, and if travellers, who have met with these birds in the North, during the season of courtship, and incubation, and in other months on classic ground, do not give any other answer to inquiries than those rendered to the Samothracian by the borderers on the Po, (who, admitting that a few Swans were now and then seen upon the river and the marsh, added, that they made a noise so disagreeable, that crows or ravens might pass for Syrens before them, we are not to conclude, that its musical powers have degenerated from former acknowledged excellence, or that they are only excited at certain periods, or in particular countries. 'The grave opinion of the great naturalist, Pliny,- the blunt assertions of Flian, the friend of the marvellous, (whose testimony on this point has been strangely misquoted,) - the playful ridicule of Lucian,-and the critique of Alexander Myndius, found in Athenæus, might be brought forward to prove that the notion was not universally admitted. Even Virgil himself, who, indulging a strong popular prejudice to enrich his verse, and give effect to his flattery, styled the Swans tuneful and harmonious, has also made them the subject of comparison with a noisy tumult :-

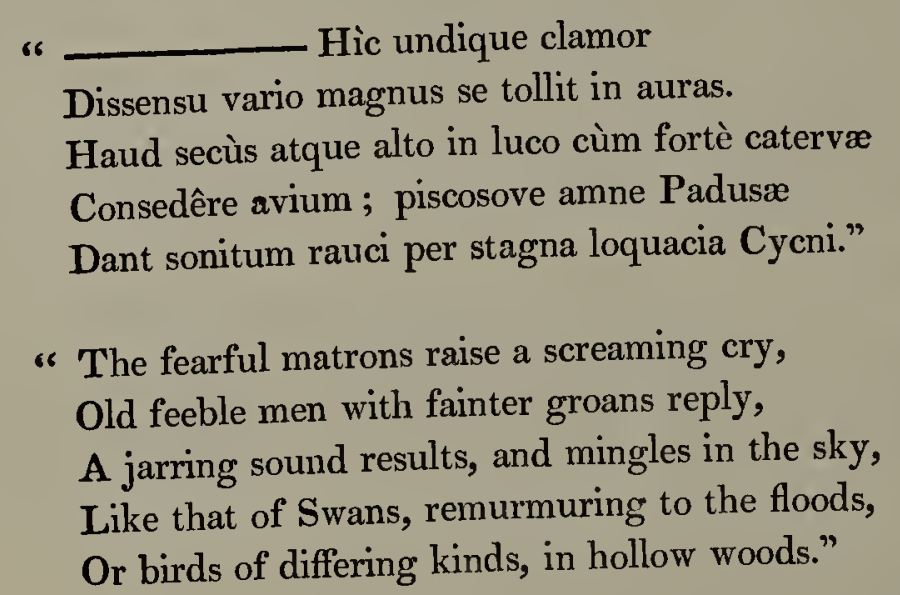

" The fearful matrons raise a screaming cry, old feeble men with fainter groans reply, A jarring sound results, and mingles in the sky, Like that of Swans, remurmuring to the floods, Or birds of differing kinds, in hollow woods."

An old Greek proverb has been brought forward by Mr. Morin to decide the controversy :-

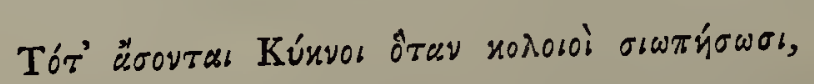

which he would have translated "The Swans will sing, when jackdaws cease to chatter, that is, never." But the real sense of the proverb seems to be, that the learned, alluded to by the term Swans, will speak when not prevented by impertinent babblers; or, that the immortal eloquence of the wise will survive the prating of fools.

Equally romantic is the supposition, that, when a Swan dies, its companions crowd around the deceased, and lament its fate in mournful requiems, after the manner of the Ligurian King, metamorphosed into this bird in the act of lamenting the son of Clymene, according to Ovid:-

" Fit nova Cycnus avis." 


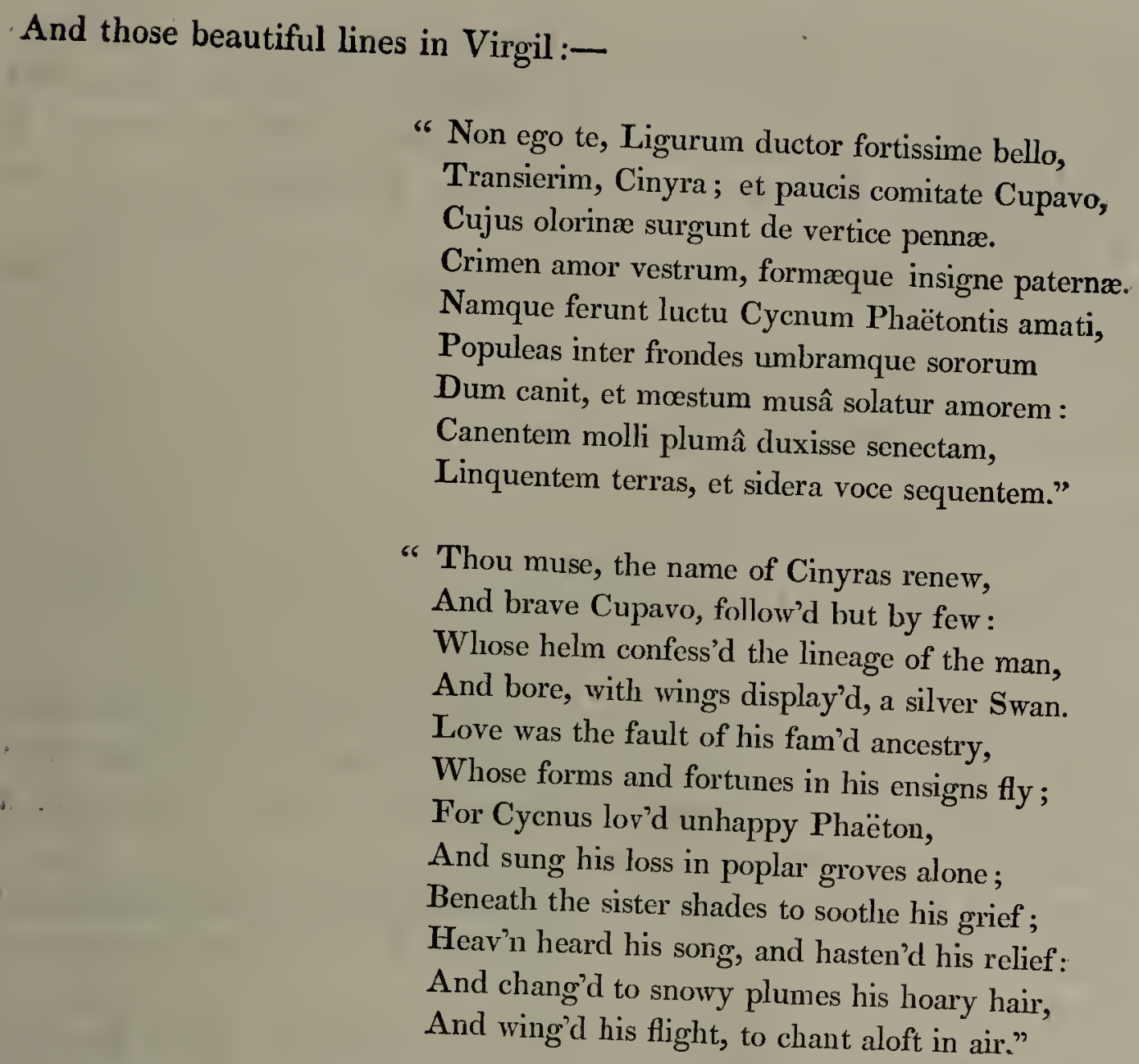

Montague seems to have had some reason for allowing the possibility of this last pleasing fiction, and would make it the source of the other, which gives it the reputation of singing its own elegy.
But the only bird, which fell to my lot inaccessible to myself, on the evening of descried from a liill, as it was lying wounded on an islet without mourners, the whole of the 23 the 22nd of February. There it died, and remained alone, adventurous labourer. Of the indifference and on the following morning it was picked up by an to the fowler, I have been repeatedly assured, by ock to those of their companions, who fall victims

But the daily song, and the dirge of death, are not who has had many opportunities of judging. regard to the Swan. Its sturdy strength and pugilio the only delusions that have been fostered with nursery anecdotes. It has been said, that a bric prowess have been the theme of more than reality its own bones are hollow, and yield in a struggle with those of any human bor flight, rather than for battle, and would soon courage. That a tame Swan might be an objeing, not destitute of presence of mind and common gander, is very possible; but I should be mject of terror to a child, who would run away from a danger that might arise from too near an approach o violence, that might be displayed by the suppe the

I would not deny to the

it would fall behind other classes of thertion of strength in defence of its offspring, without which, parental promptitude for necessary com feathered race. Thomson has beautifully described its

\footnotetext{
" The stately sailing Swan

Gives out his snowy plumage to the gale,

And arching proud his neck, with oary feet

Bears forward fierce, and guards his osier isle,

Protective of his young."
} 
Naturalists have been also much in error as to the food of the Whistling Swans. According to some they are carnivorous. Aristotle, I think, says, they will eat one another. Mr. Buffon states, that they feed upon fish, particularly eels, also upon frogs, leeches, slugs, and grass. But the contents of their stomach are always found to consist of vegetable matter, grass, water-weeds, and, in one instance that came before me, of corn.

Virgil is nearer to the truth, as to their means of sustenance, in his account of the environs of his native town:-

Et qualem infelix amisit Mantua campum,

Pascentem niveos herboso flumine Cycnos.

Or such a field as hapless Mantua lost,

Where silver Swans sail down the wat'ry road,

And graze the floating herbage of the flood.

To seek the roots and weeds, which grow at the bottom of lakes and rivers, says the Bolognese Professor, these Swans are supplied with a long and strangely formed windpipe, which enables them to keep their necks for a long time under the water; - a remark sanctioned by the experience of a very acute, and observing Ornithologist in this county.

The sacred Historian, however, (if the Hebrew term be rightly interpreted in the Septuagint,) places the Swan in the catalogue of unclean fowls. But, at any rate, it is included with others, which are not birds of prey, for instance, the lapwing.

We shall not in these days be reproached for passing over the story of a feather, which has been said to descend by degrees from the Swan's forehead into the brain, to divide the last thread of its existence.-It is spoken of by Bartholinus.

The flesh of the Whistling Swan, to my taste, is scarcely eatable. I partook of one in the neighbourhood of Selborne, where I could not help regretting, that the subject of my Letter had not met with the special attention of the great "Oionoscopus" of that village.

Several Swans were submitted to epicurean experiments during the winter. At Holdenluurst one, whose skin I purchased, was distributed by the man who killed it, in joints and pasties to his poor friends and neighbours. At Gloucester a public ordinary was held, for the purpose of feasting upon two, which were shot near Frampton-upon-Severn. The ticket sold at an extravagant rate, I have been told, for a guinea.

Dr. Krasheninicoff, in his Account of Kamtschatka, declares, that this forl is as popular as common in that country, (where it is called "Matame,") and that no person, rich or poor, could think of having an entertainment without one.

There has been no arrival of these Swans, in our degree of latitude, to compare with that of this year, since the winters of 1784-5, and 1788-9; when they extended to the marshes of Abbeville, in Picardy, in considerable numbers; some were seen at Châlons-sur-Saone, in Champagne; and many on the broad rivers beyond the Alps. In 1819 many were brought to Leadenhall market, from Lincolnshire. This year a friend of mine saw sixty exposed for sale in London in one day.

Some of these emigrants remained with us until the end of March; and it was expected, that, as the purpose of extermination had been checked by the considerate interference of the proprietors of the district, the birds would remain, and multiply. But they returned to the country, whence they visited us, as soon as the South-Westerly gales set in, although every encouragement of peace was held out to them, for at least a month previous to their departure.

An attempt was made to keep one in confinement at Harbridge; but the poor thing became emaciated, and died, after having decreased in weight from twenty-three pounds to five. 
Dr. Maton, in his Observations on the Western Counties of England, published at Salisbury in 179\%, affirms, that the Whistling Swans are inhabitants of Dorsetshire, where he found them, in the summer, on the East side of the Chesil Bank, near Weymouth. But these were probably a few lingerers, disabled, or separated by some mis-chance from the band of returning emigrants. In contradiction to his statement, it is said, that they might have been stray individials of the mute species, from Lord Ilchester's, at Abbotsbury. But I have no doubt of his having really seen, what those, who have read his amusing tour, (now become a very scarce book,) will find he compared with some of the natives of the Swannery.

The residence of the Whistling Swan in Northern regions, and its periodical migrations towards the South, have been satisfactorily ascertained, on the new Continent, as well as on the old. According to Colonel Davis, they breed on the unfrequented borders of the upper Lakes in America, and descend with their young, about the beginning of October, as far as Carolina. In the Zoological Appendix to the story of a disastrous, but bold, and highly interesting Expedition to the Polar Sea, Mr. Sabine remarks the migration of this species to Southern parts during winter, in search of sustenance, and their return to the more solitary scenes of the Arctic Circle, to rear their progeny. Captain Franklin, in the journal bearing date April 15th, 1820, observes, that some of these Swans flew over the houses at Fort Chipervyan, and adds, that these are generally the first birds of passage, which arrive from the South, and that the flight, to which he alludes, had been retarded in its progress from a lower district, (where it had been previously seen on the 8th of April,) by very stormy weather.

Their summer haunts in the North of Asia have been noticed by many, on whose testimony reliance can be placed, and also their descent on the approach of cold weather, from the wilds of Siberia to the meandering streams of the Cayster, and sometimes even to the broad channels of the Nile.

Their progress, along our parallel of longitude, from Lapland to Iceland, ihe Orkneys, Western Islands, and Scotland, takes place every winter, in regular gradation; and, as in this season, they advance to warmer latitudes in proportion to the inclemency of the winter, and the consequent scarcity of food. They come, says Martin, about October every year, in great numbers, to Lingey, one of the Hebrides, and continue there until March, when they retire to less frequented lakes and forests, to devote themselves to their offspring. They visit the Orkneys every winter, and return to more Northerly situations on the approach of Spring. And in these islands, the Swan is the poor man's only almanack, so regular are its movements, and such the change of temperature which attends them.

Thus this part of creation adds its tribute of obedience to the laws and ordinances of the great God of nature ; - an example, which it becomes enlightened and rational man to follow. These birds know their appointed seasons, and observe the time of their coming. Let them remind us, that here we have no abiding city, but that it is our duty and high privilege to prepare for a removal from earth to heaven.

With affectionate regard,

I subscribe myself,

Your sincere Friend,

THOMAS COOKE. 


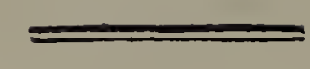

a-The Sternum.

$b$-The Keel.

c c - The Clavicles.

d-The Furcula.

$e$-The Glottis, covered with papillæ, which answer the purpose of the membrane called the Epiglottis, and prevent the food from falling into the Trachea.

$f f f f-$ The Trachea with its inflexion and return.

$g-$ The compressed Larynx.

$h$-The Bronchi.

i-The Cavity, or receptacle for the Trachea in the Keel. 


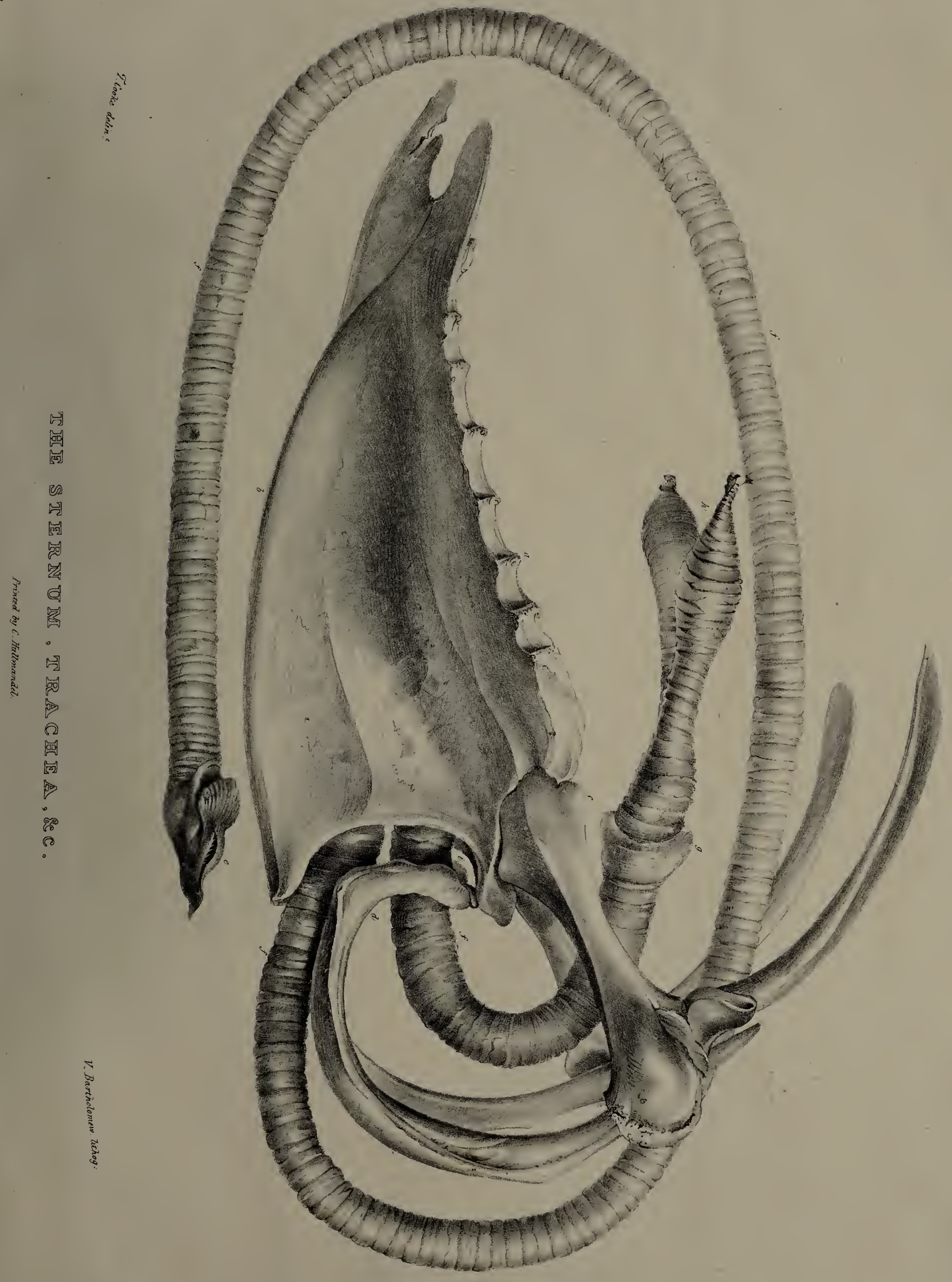






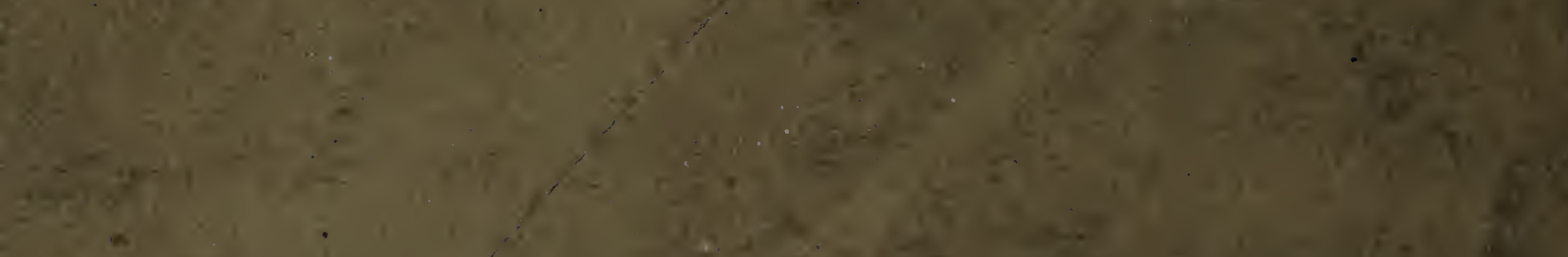

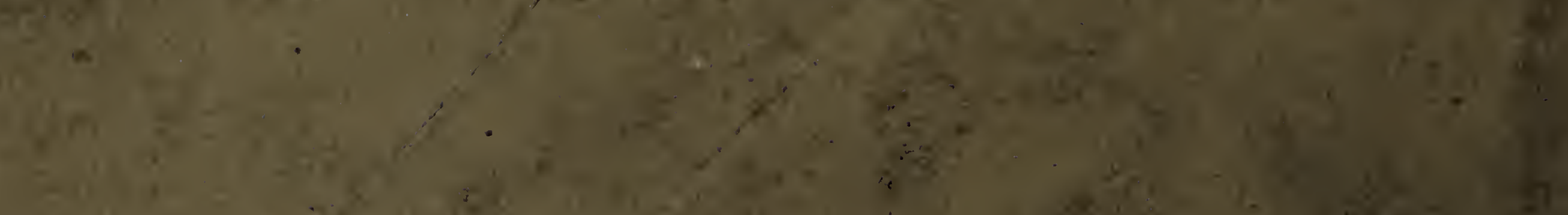

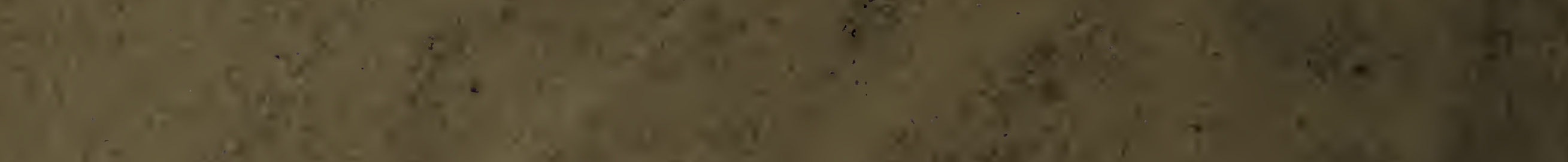

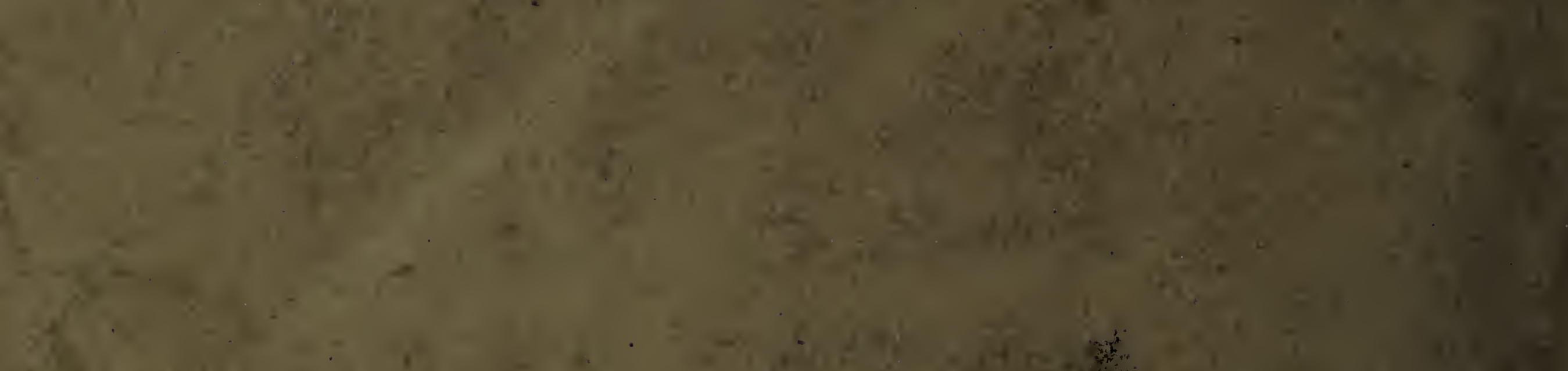

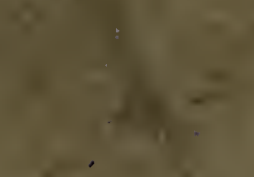

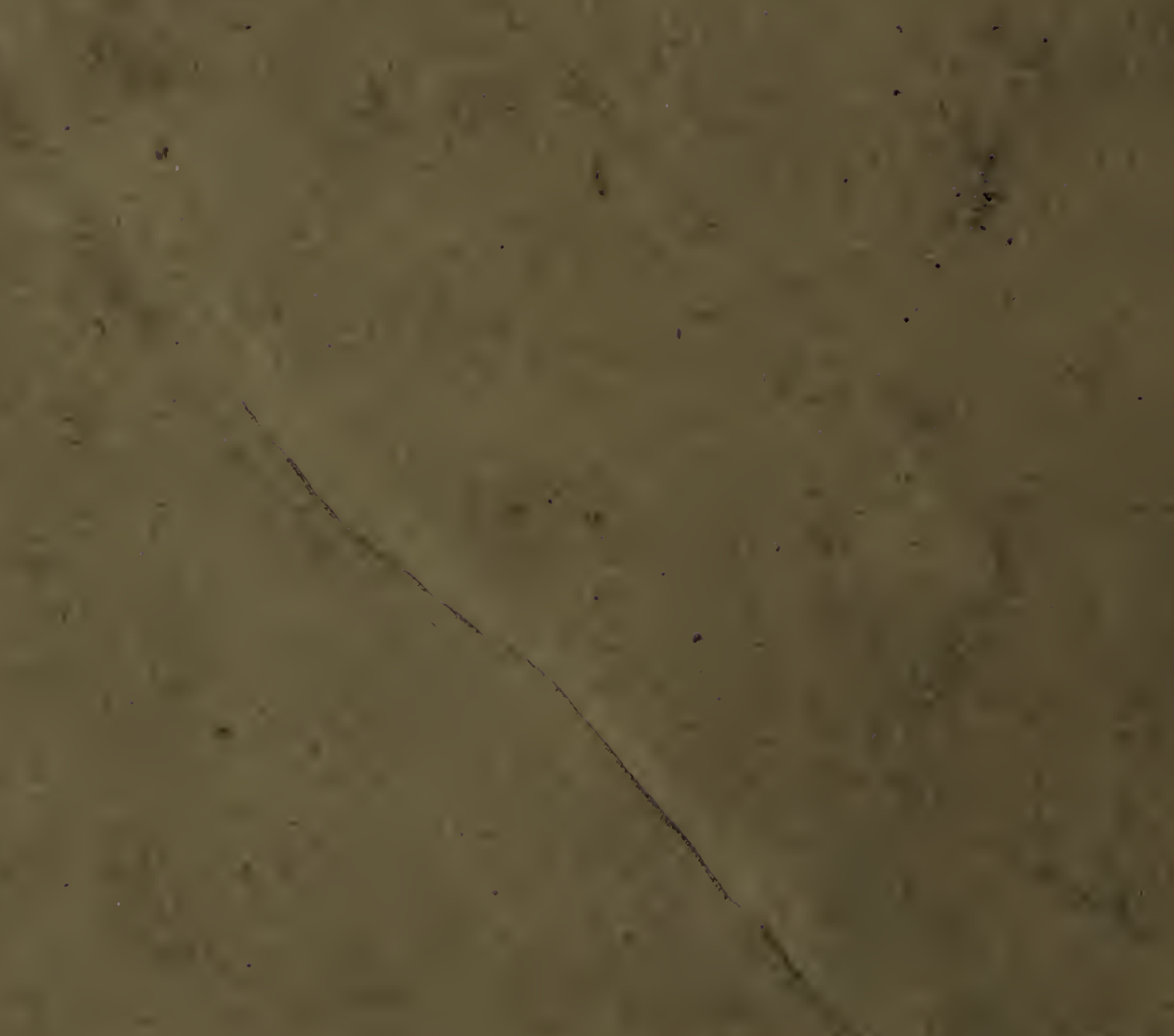

aten

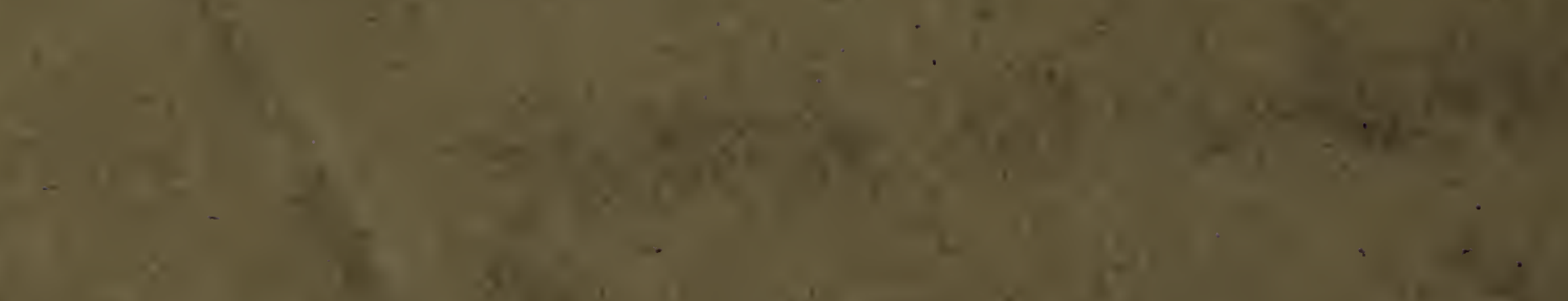

in
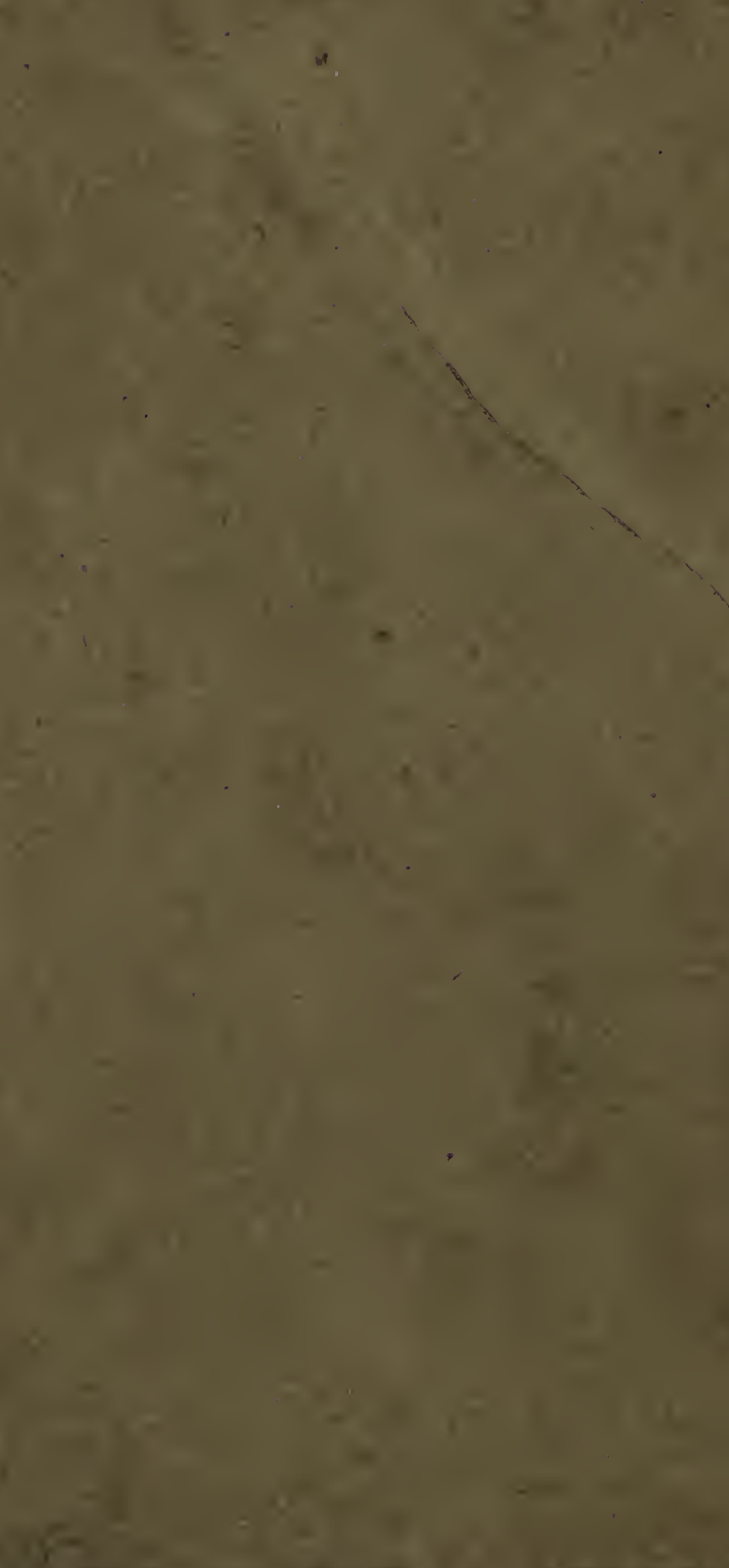

4
7
7

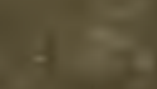

$86: 5 x+5=$

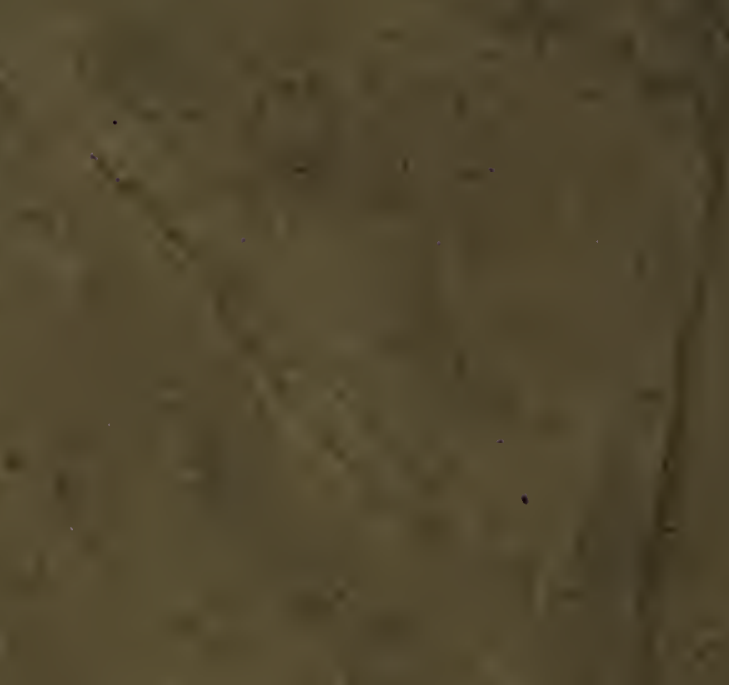

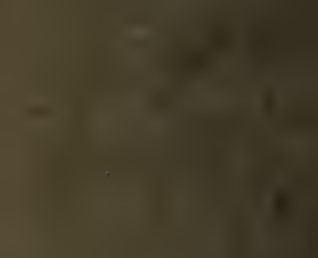

1 


\section{1}

1

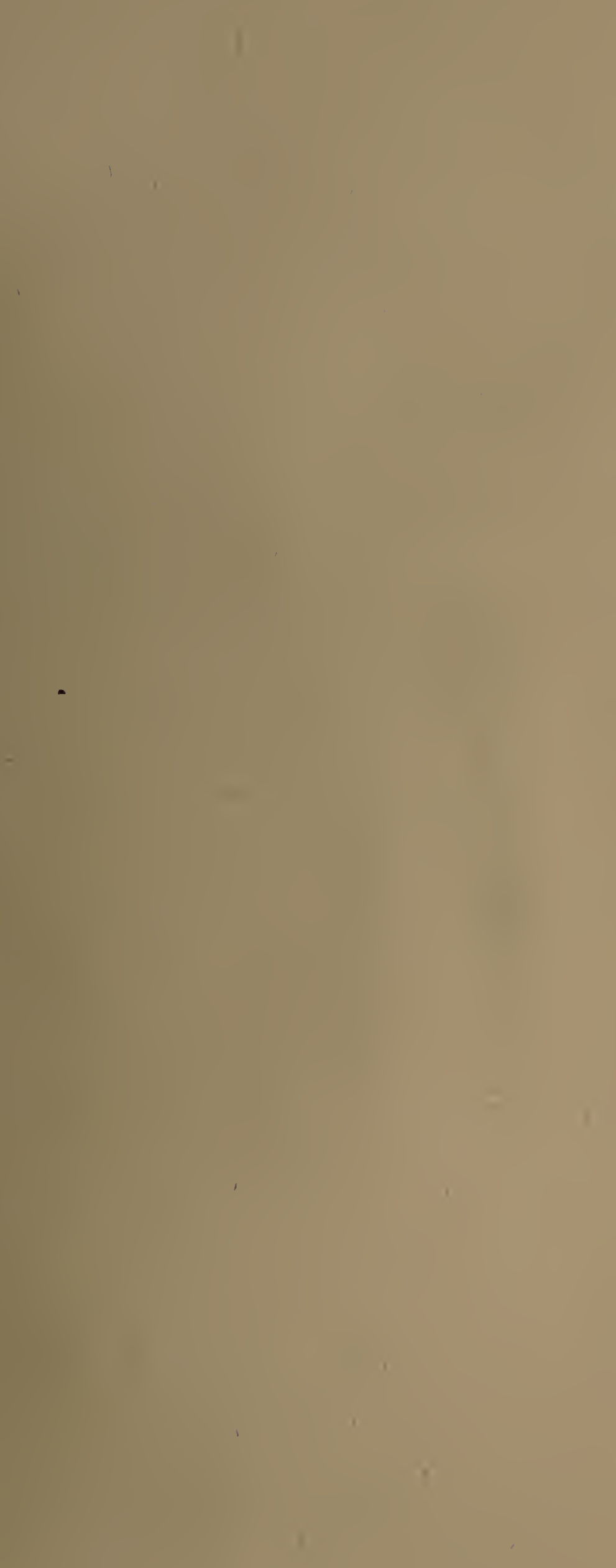

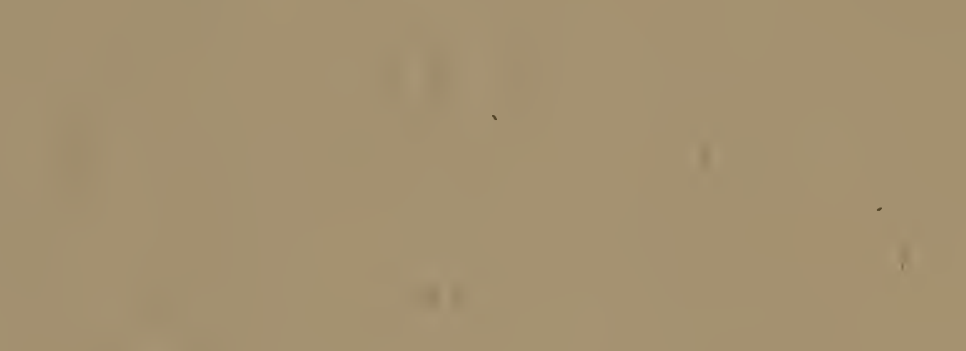

1

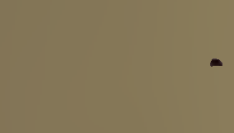

-
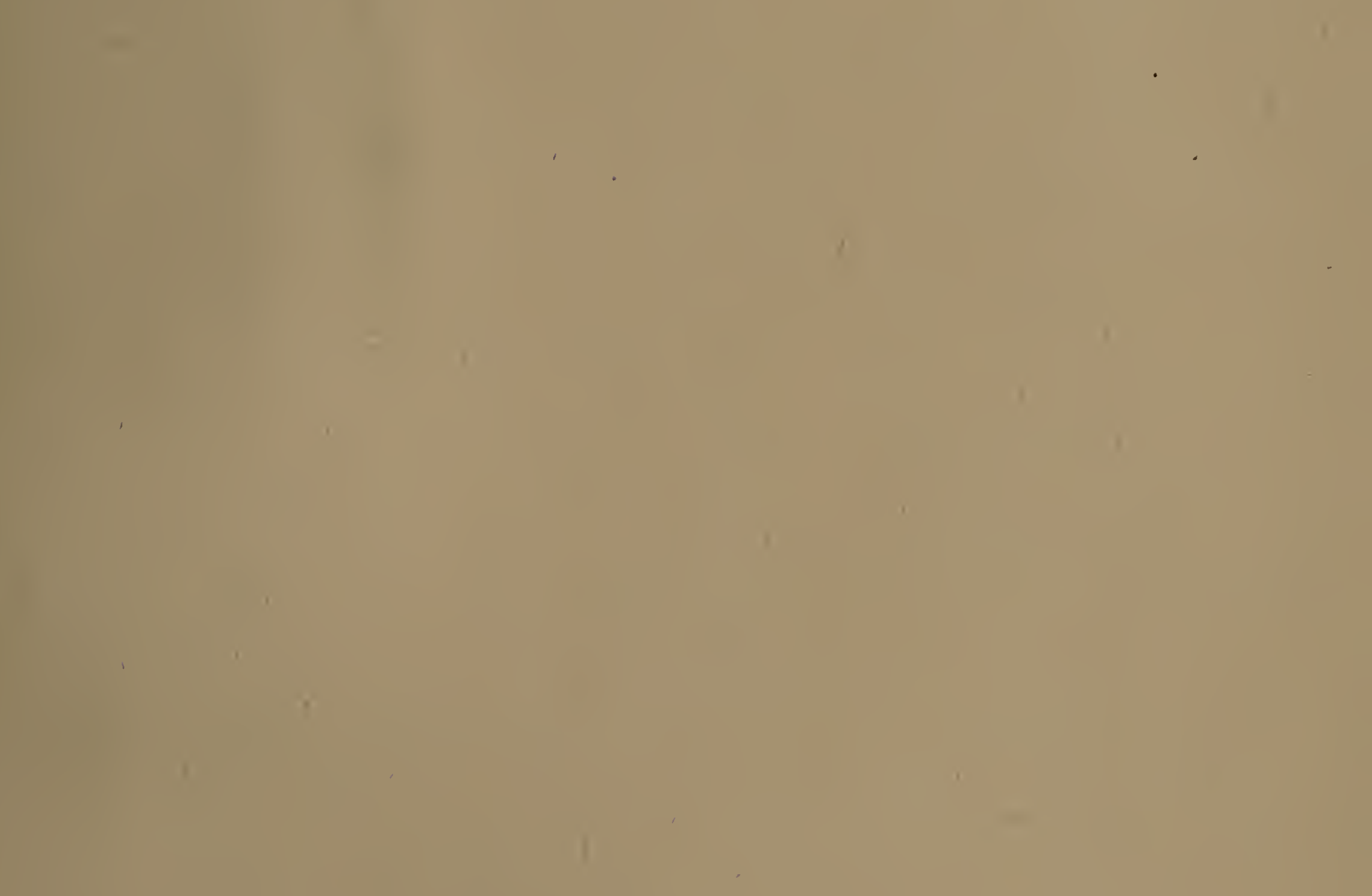

1.

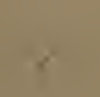





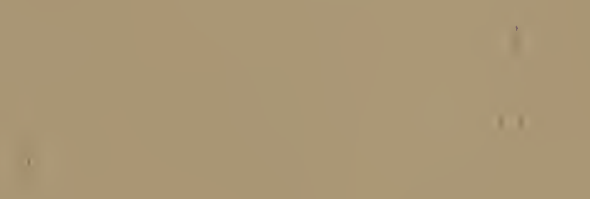




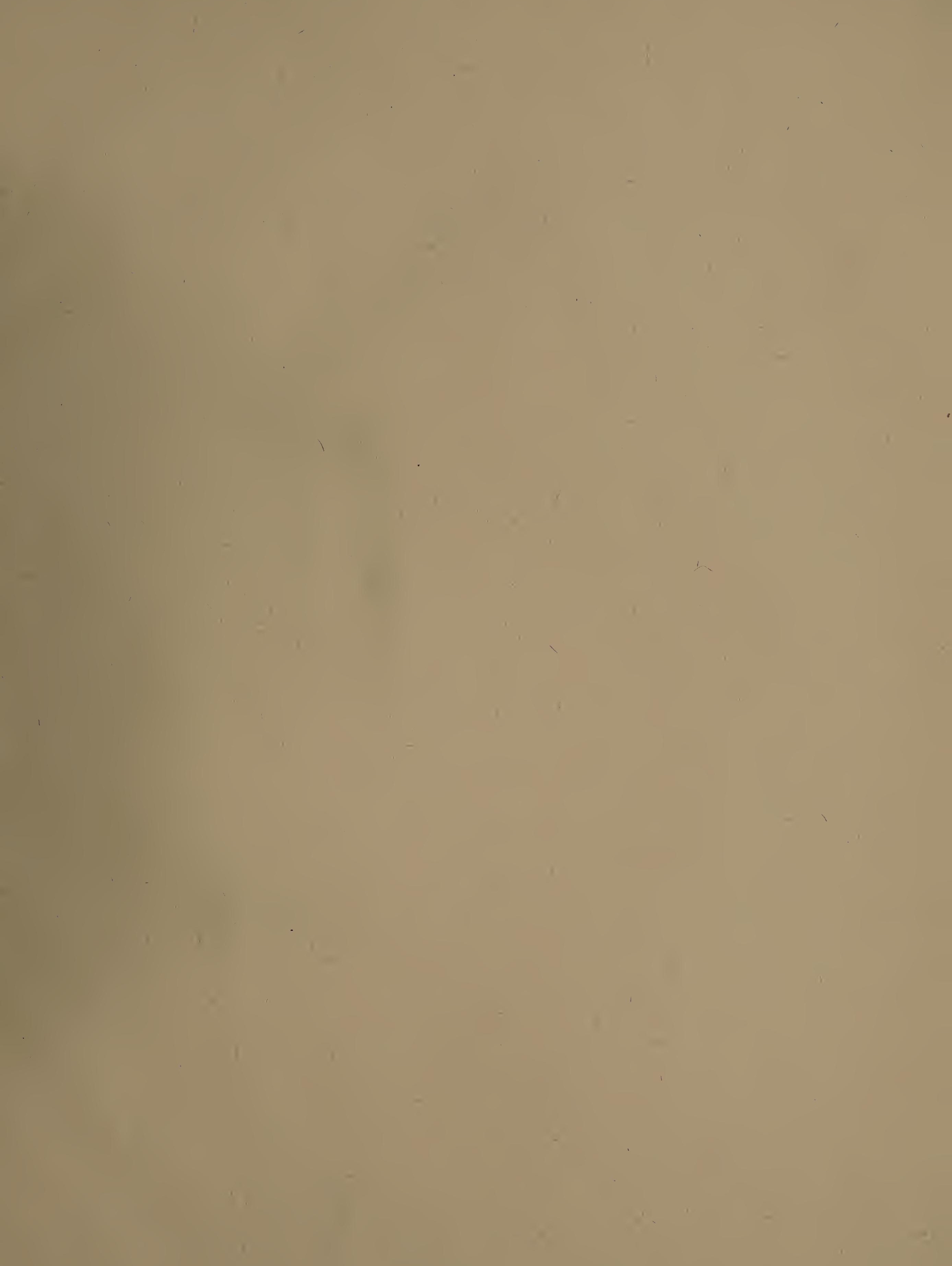


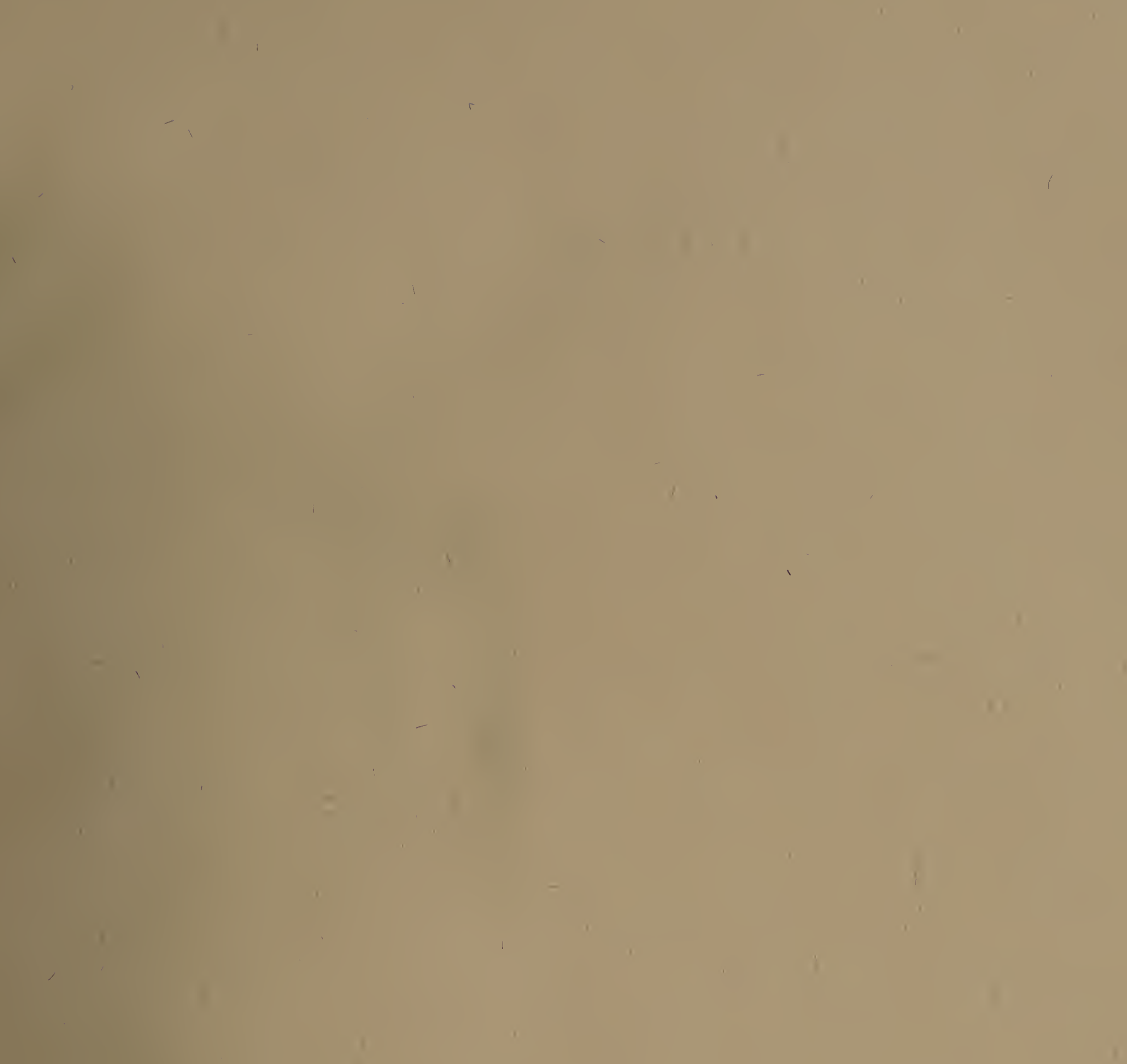

, 



\section{1 \\ ।}




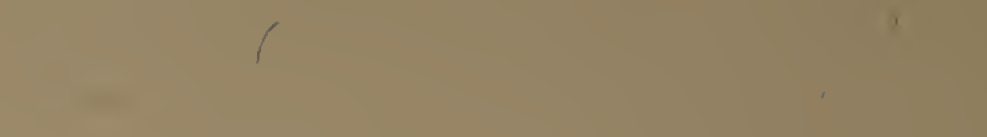

$1+1$

x

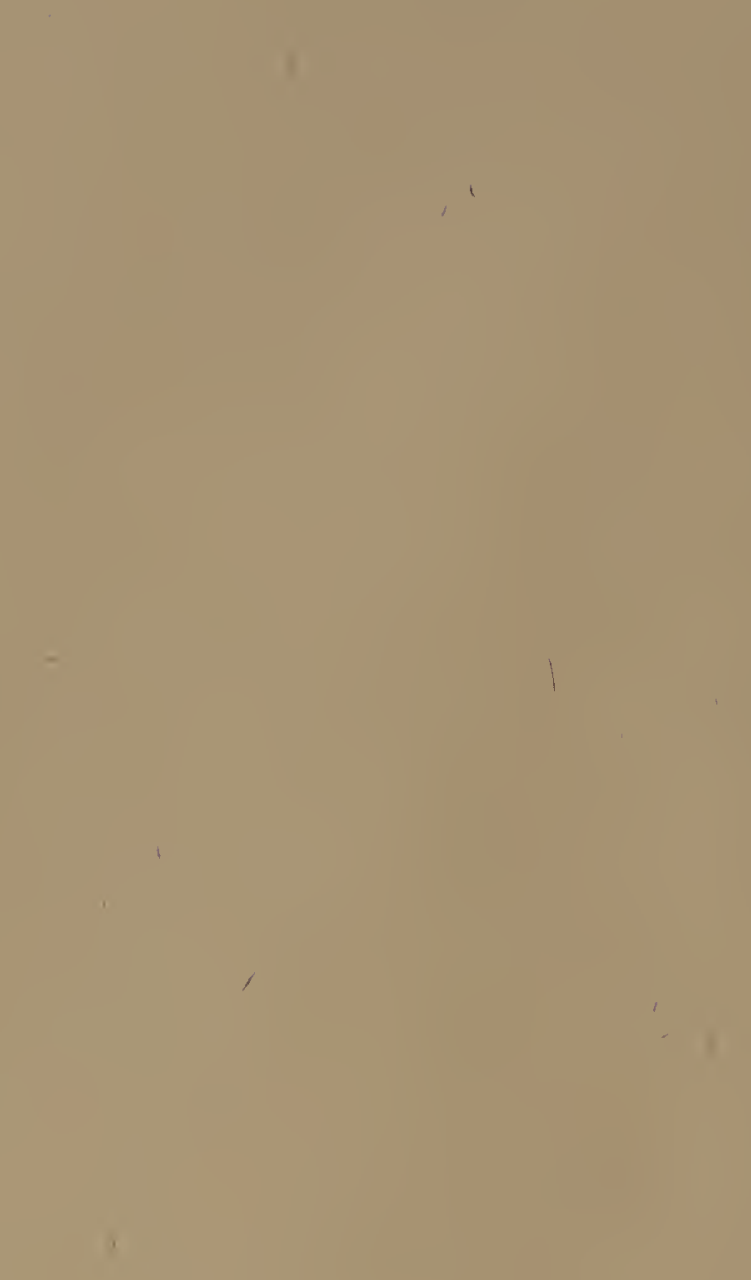

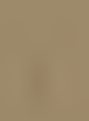

*

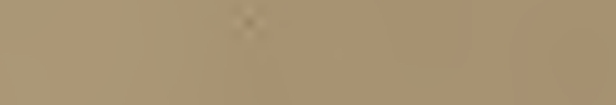


1,1

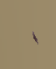

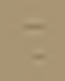




I

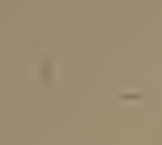





\section{YIf}

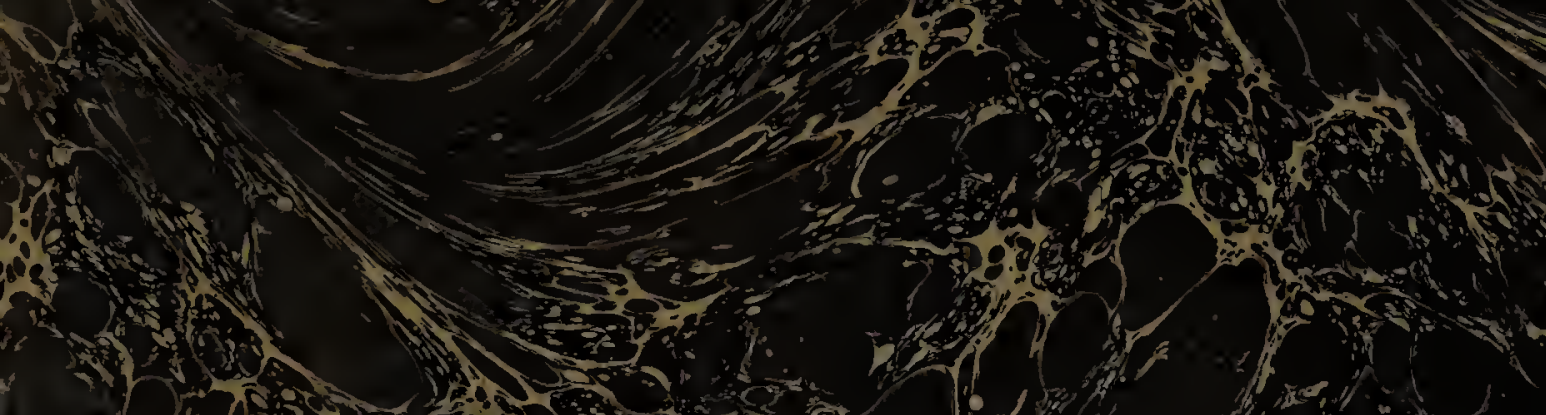
3.1.

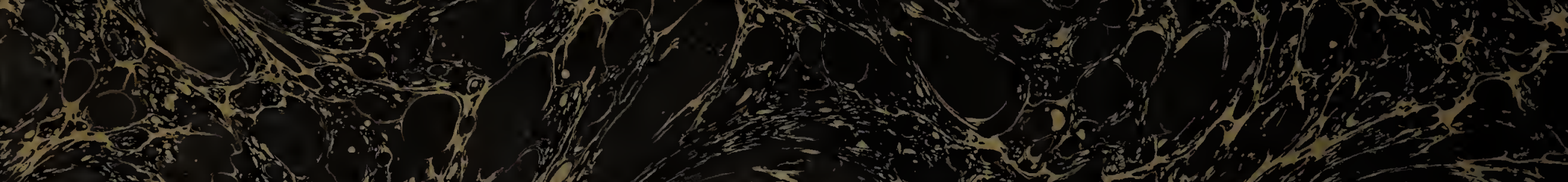

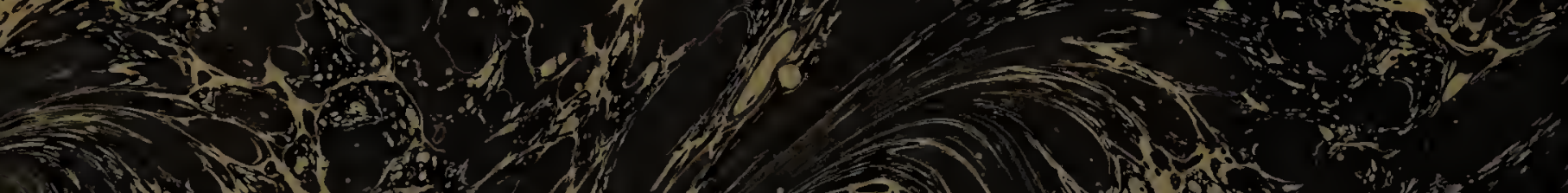

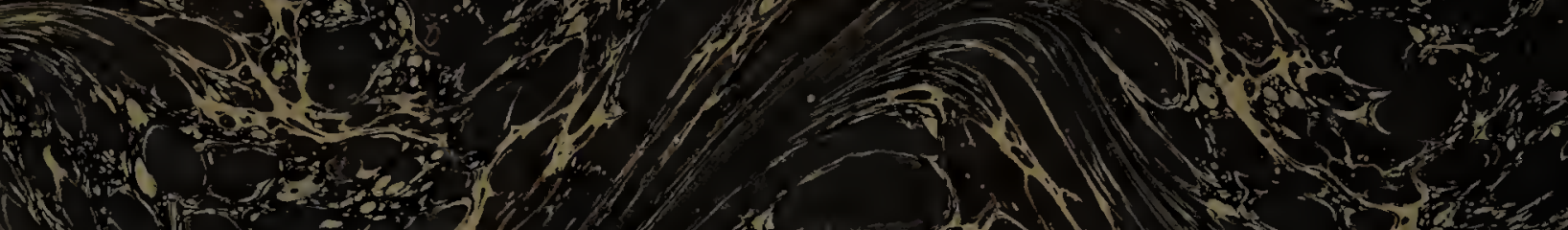
(1)

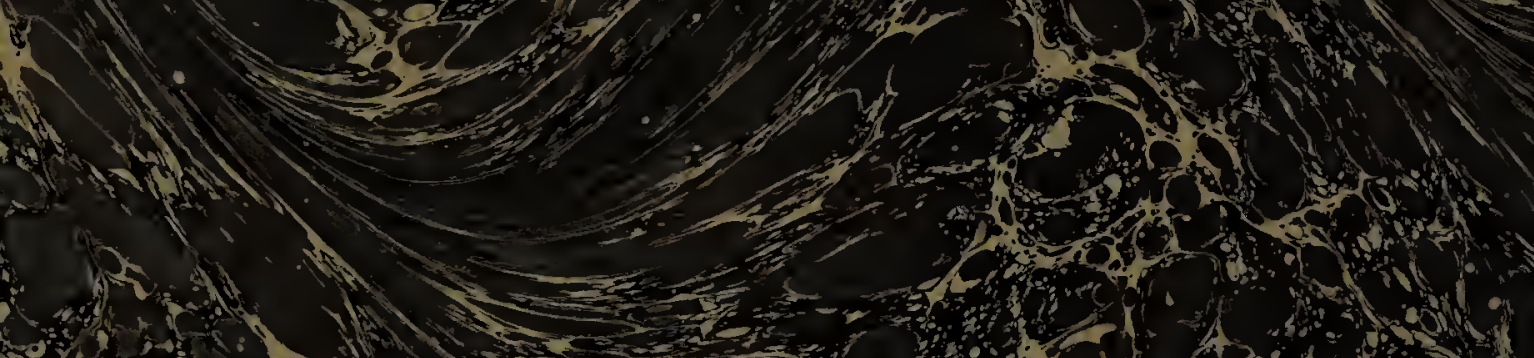

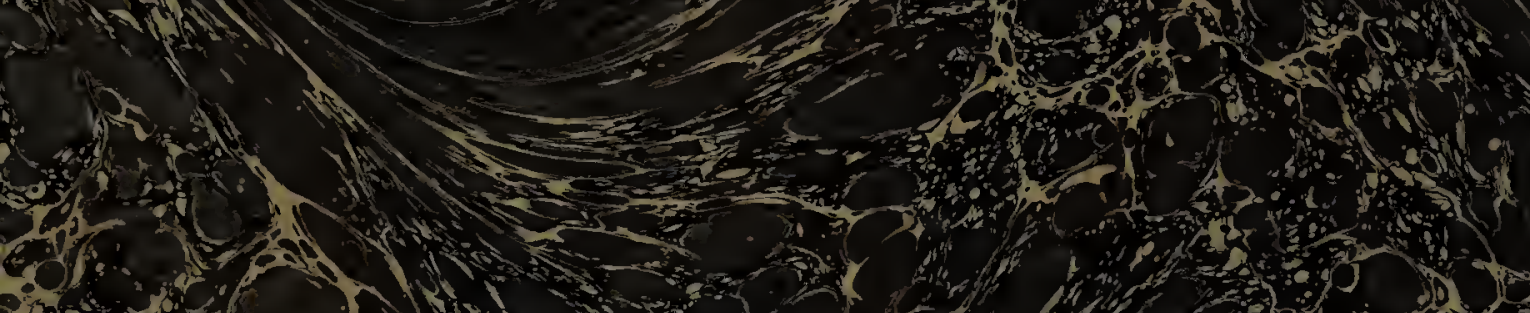

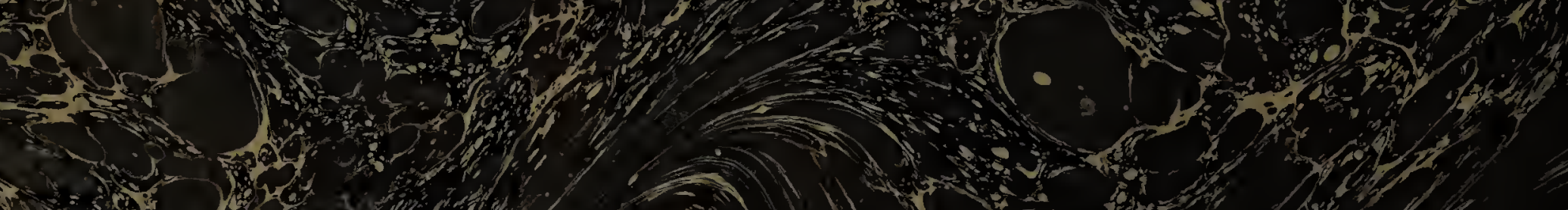

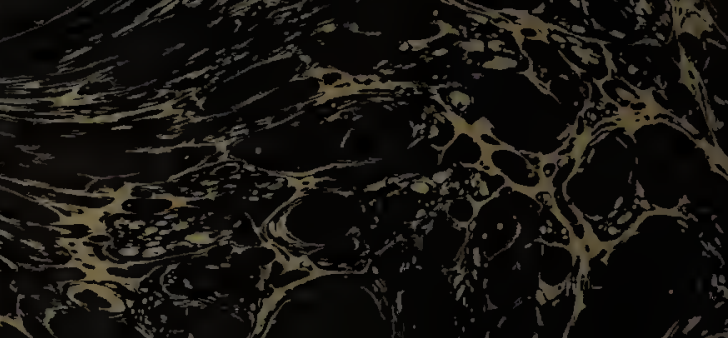
(2.1.7.

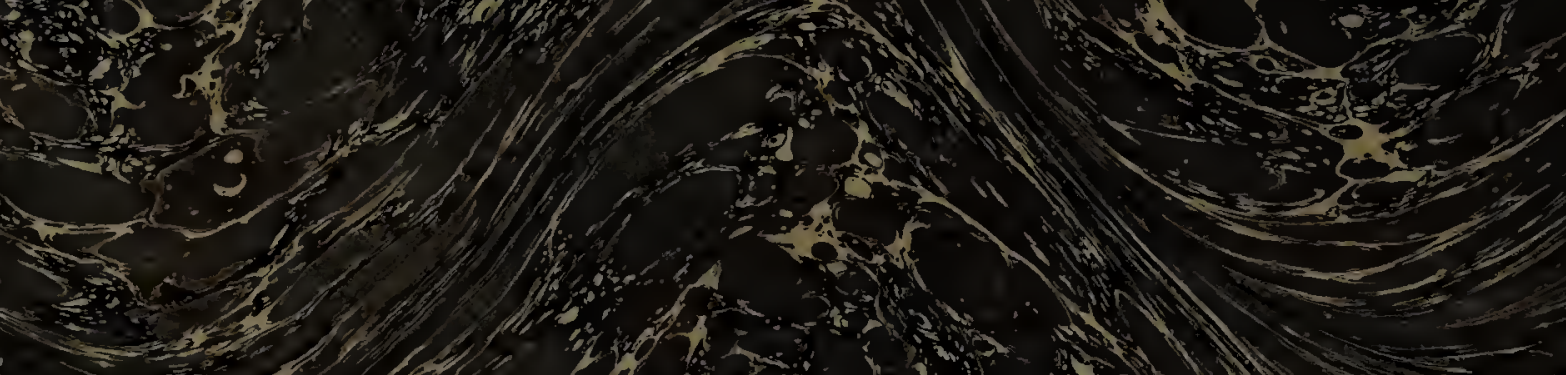

\section{S}

5

3. 3.

5

(2)

(1) t.

1

(N)

$x_{-1}=2$

3.

-

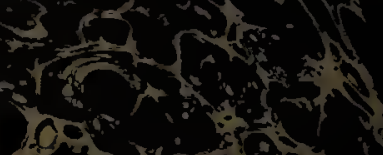

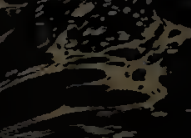

$-$ 